\title{
PD01-1 食道癌治療後の下咽頭癌に対する外科的治療の問題点
}

藤賢史，福島淳一，白土秀樹，中島寅彦，小宗静男

九州大学 医学部 耳鼻咽喉科

【背景・目的】頭頸部癌には重複癌が多く、特に下咽頭癌では食道癌が高率に重複 する。下咽頭癌に対しては、多剤併用した化学放射線療法 (CCRT) が積極的に導入さ れる一方で、局所進行癌に対しては手術が必要となる症例が少なくない。重複食道癌 がある場合、いずれの治療方針でも頸胸境界部の前治療により治療方法が制限された り、関連する合併症に難渋したりすることがある。そこで、下咽頭癌に対する外科的治 療において、重複食道癌に対する治療の他に、頚部に対する CCRT や合併症などの 関連因子が、頸部手術やその合併症に与える影響について検討した。

【対象・方法】 2007 年から 2011 年までに九州大学病院において治療を行った下咽癌 症例のうち、遊離空腸移植を併施する咽喉食摘術を施行した 48 例。

【結果】 17 例 (35\%) に重複癌を認め、11 例が食道癌であった。局所合併症は 18 例に 認め、頸部の術後血腫 (6 例)、吻合部狭窄 (6 例) 等であった。移植腸管の全壊死や 大血管の破綻など重篤な合併症は認めなかった。局所合併症は食道癌重複例では

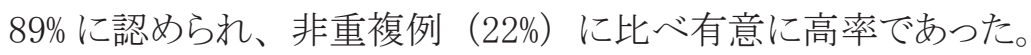

【結論】胸部食道癌の治療歴のある下咽頭癌症例に対する外科的治療はおおむ称安 全であるといえるが、局所合併症の頻度は高いことが予想される。吻合部狭窄など長期 にわたり QOL を低下させる可能性があり、慎重な周術期の管理や感染症への対策が 必要であると考えられた。

\section{PD01-2 頭頸部および食道の重複癌における臨床的病理学的特徵と治療成績の 検討}

江頭明典 ${ }^{1}$, 森田勝 ${ }^{1}$, 藤也寸志 ${ }^{1}$, 大垣吉平 ${ }^{1}$, 前原伸一郎 ${ }^{1}$, 南一仁 ${ }^{1}$, 池田康治 ${ }^{1}$, 坂口善久 ${ }^{1}$, 檜垣雄一郎 ${ }^{2}$, 岡村健 ${ }^{1}$

${ }^{1}$ 独立行政法人 国立病院機構 九州がんセンター 消化器外科, ${ }^{2}$ 独立行政法人

国立病院機構 九州がんセンター 頭䅡科

【目的】食道・頭頸部重複癌の治療成績を検討し、臨床的特徵および治療戦略を考 察する。【方法】 2003 年以降、当院にて治療した頭頸部および食道の重複 50 例を対 象とし、臨床的特徵、治療成績を検討。【結果】1. 臨床的特徵 : 頭頸部癌は、口腔 癌 6 例、咽頭癌 29 例、喉頭癌 4 例で、III 期 4 例、IV 期 17 例と進行癌が多かった。 食道癌は 0 期 15 例、I 期 13 例と早期症例が多かった。2. 治療内容 : 食道癌に対し 内視鏡的切除 9 例、手術 8 例、化学放射線療法（CRT） 21 例、頭頸部癌に対し手 術 8 例、CRT29 例、化学療法 1 例。同時 CRT は 20 例に、6 例に咽・喉頭・食道 全摘術がなされた。3. 同時 CRT：画像上 CR は食道癌 13 例 $(65 \%)$ 、頭頸部癌 11 例 $(55 \%)$ 。CRT 後の食道癌が遺残または再発した 11 例に対し、治療（内視鏡的治 療 3 例、腔内照射 2 例、化学療法 2 例、CRT2 例、サルベージ手術 1 例）がなされた。 一方、頭頸部癌の遺残・再発した 11 例中、 7 例に手術（切除 3 例、頸部郭清 4 例）、 化学療法 1 例がなされていた。同時性 CRT 後の 2 および 5 年生存率は $67 \%, 60 \%$ であっ た。4. 咽・喉頭・食道全摘 :6 例中術後合併症として 1 例に縫合不全、乳糜胸を認 めた。2 例は術後 4, 52 ヶ月にて癌死したが、 4 例は術後 29-57 ケ月現在生存。【考察】 CRT、切除等を組み合わせた集学的治療を行うことにより比較的良好な予後が期待でき る。外科・頭頸科等の複数科の綿密な連携による治療方針の決定と遺残・再発病巣 に対する対策が重要と考えられた。 


\section{PD01-3当院における咽頭喉頭頚部食道全摘出術についての検討}

西田康二郎 ${ }^{1}$, 中八子智徳 ${ }^{1}$, 由茅隆文 ${ }^{1}$, 吉田倫太郎 ${ }^{1}$, 植田直之 ${ }^{1}$,

播本憲史 ${ }^{1}$, 永田茂行 ${ }^{1}$, 古賀聡 ${ }^{1}$, 甲斐正徳 ${ }^{1}$, 三橋拓之 ${ }^{2}$, 山内俊彦 ${ }^{3}$, 梶山潔 ${ }^{1}$

${ }^{1}$ 飯塚病院 外科, ${ }^{2}$ 飯塚病院 耳鼻咽喉科, ${ }^{3}$ 飯塚病院 形成外科

【背景】咽頭喉頭澒部食道全摘出術（咽喉食摘術）は、主に下咽頭癌, 喉頭癌, 頚 部食道癌（下咽頭進展例, 気管浸潤例）に対して選択される術式である。当院では再 建方法として遊離空腸移植を行なっており、耳鼻科, 形成外科, 外科, 時には口腔外 科を含めた複数科で手術を施行している。【目的】当院における咽喉食摘術について、 各科の役割分担と連携、およびその効果について検討する。【対象と方法】2006 年〜 2011 年に当院で施行した咽喉食摘術症例 33 例を対象しして、年度毎の各科連携方法 の変化、手術時間、術後合併症発生頻度について検討した。【結果】頚部郭清 : 耳 鼻科, 腹部操作および䅡部吻合 : 外科, 頚部血管吻合 : 形成外科と、明確な役割分 担の下で手術を施行した。下顎骨正中離断を要する症例では口腔外科が同操作を担 当した。総手術時間、術後合併症発生頻度は年度間で有意差を認めなかった。2011 年に術前全科合同カンファレンスを導入したことによって手術中の待機時間が減少し、 より円滑な手術進行が得られるようになった。今後さらに安全で円滑な手術を行っていく ために、麻酔科を含めた全科の連携強化が必要であると考えられた。【結語】複数科 で行なう手術においては、術前からの術式の詳細な検討や全科の意思統一が特に重 要である。

\section{PD01-4 三科共同で行った下咽頭喉頭全摘術の経験}

太田徹哉 ${ }^{1}$, 森秀暁 ${ }^{1}$, 長岡知里 ${ }^{1}$, 丸中秀格 ${ }^{2}$, 赤木祐介 ${ }^{2}$, 濱田浩司 ${ }^{2}$, 末延耕作 ${ }^{3}$, 高田温行 ${ }^{3}$, 徳岡晋太郎 ${ }^{3}$

${ }^{1}$ 国立病院機構 岡山医療センター 外科, ${ }^{2}$ 国立病院機構 岡山医療センター 耳 鼻咽喉科, ${ }^{3}$ 国立病院機構 岡山医療センター 形成外科

右下咽頭癌 (T4bNOM0 stage IVB) に対して、耳鼻咽喉科・外科・形成外科の三科共 同で下咽頭喉頭全摘術 (TPLE) を施行した。【症例】70 歳男性。喉頭ファイバーにて 右下咽頭から右喉頭にかけて表面不整な腫瘍と声帯麻㿁を認めた。CT・MRI では遠 隔転移を認めずTPLEの適応と判断した。耳鼻咽喉科より手術を開始し、咽頭・食道 は病変から約 $3 \mathrm{~cm}$ のマージンをもうけて切除し、両気管傍+右レベル I 〜 IV+右甲状 腺摘出 + 喉頭食道摘出 + 永久気管口作成を行った。病変摘出後、外科が腹部操作に 入り空腸採取の準備を行い、形成外科による頸部の血管吻合準備ができた段階で空腸 を切離。温阻血下に遊離空腸を頸部へと移動し、空腸動脈 - 上甲状腺動脈、空腸静 脈一総顔面静脈の端端吻合を行った。この間、外科にて腹腔内の残空腸端端吻合を 行い、頸部血管吻合が終了した段階で咽頭 - 遊離空腸吻合（端側吻合）及び遊離空 腸 - 胸部食道吻合（端端吻合）を行い遊離空腸移植再建を終了した。再度腹部操作 に戻り、腸瘻作成した後に閉腹。その間、頸部は形成外科にて右 DP 皮弁を用いて皮 膚再建を行い、皮弁採取部は右大腿より分層網状植皮を行って手術を終了した。手術 時間 10 時間 57 分、出血量は $700 \mathrm{ml}$ にて、術後は特に縫合不全を認めず良好に経過 した。【結語】専門領域の異なる診療科が共同して手術を行う際には、術前の綿密な シミュレーションと、術者同士の良好なコミュニケーションが必要と思われた。 


\section{PD01-5 咽頭喉頭食道摘出術後の再建法と治療成績}

渡邊雅之 $^{1}$ ，馬場祥史 ${ }^{1}$ ，長井洋平 ${ }^{1}$ ，井田智 ${ }^{1}$, 村上大造 ${ }^{2}$ ，國友隆二 ${ }^{3}$ ，

馬場秀夫 ${ }^{1}$

${ }^{1}$ 熊本大学 消化器外科, ${ }^{2}$ 熊本大学 耳鼻咽喉科頭頸部外科, ${ }^{3}$ 熊本大学 心臓 血管外科

咽頭喉頭食道摘出術（咽喉食摘）後の再建には消化器外科、耳鼻咽喉科、血管外 科による協力体制が必要である。特に食道癌を併存し食道全摘を併施する症例ではよ り複雑な再建術が必要となる。当院における咽喉食摘後の再建術の工夫を供覧し、そ の成績を提示する。【対象症例】 2008 年 4 月〜 2011 年 12 月咽喉食摘を施行した 25 例（下咽頭癌 16 例、中咽頭癌 3 例、頸部食道癌 5 例、喉頭癌 1 例）を対象とした。 食道全摘は内視鏡治療困難な胸部食道癌を合併した 9 例に施行した。前治療は根治 CRT 後のサルベージが 5 例、40Gy の術前 CRT が 3 例であつた。【結果】手術手技 : 遊離空腸は第 2 または第 3 空腸動静脈を茥とするグラフトを用い、全例で総頸動脈、 内頸静脈と血管吻合した。食道全摘例での再建は胃管 + 遊離空腸 4 例、左胃動静脈 の血行再建を伴う亜全胃管 2 例、幽門洞を切除し右胃大網動静脈を有茥とした延長胃 管 + Roux-en-Y 法 2 例、左結腸 1 例であった。成績 : 再建に伴う合併症は 4 例（縫 合不全 3 例、吻合部出血 1 例）に認められ、major leak1 例と吻合部出血 1 例に再手 術を施行した。術前 CRT 症例では咽頭遊離空腸吻合部の minor leak が 1 例、食道全 摘例では咽頭遊離空腸吻合の minor leak1 例でいずれも保存的に治瘉した。血管吻合 に伴う腸管壊死は認めなかった。【考察】CRT 後の症例を含めて血行再建の成績は良 好であった。術式の工夫により咽頭喉頭食道全摘例に対しても安全に再建術を施行し 得ることが示された。

\section{PD01-6ＩCG 血管造影による下咽頭・頚部食道癌切除後再建グラフトの新しい術 中血流評価法}

神谷欣志 ${ }^{1}$, 宮崎真一郎 ${ }^{1}$, 佐野真規 ${ }^{1}$, 飯野一郎太 ${ }^{1}$, 高橋善明 ${ }^{1}$, 藤田剛 ${ }^{1}$, 菊地寛利 $^{1}$, 平松良浩 ${ }^{1}$, 太田学 ${ }^{2}$, 坂口孝宣 ${ }^{1}$, 海野直樹 ${ }^{1}$, 今野弘之 ${ }^{1}$, 細川誠二 ${ }^{3}$, 大和谷崇 ${ }^{3}$, 峯田周幸 ${ }^{3}$

${ }^{1}$ 浜松医科大学 外科学第二講座, ${ }^{2}$ 浜松医科大学 腫瘍センター, ${ }^{3}$ 浜松医科大学 耳鼻咽喉科・頭頸部外科学講座

【はじめに】下咽頭・頚部食道切除後の遊離空腸再建では、血管吻合後の腸管血流 が再建の成否を決定する大きな要因となる。ICG 血管造影は、優れた視認性により有 用な術中血流評価法として広く知られるところとなったが、その客観的評価法は確立さ れていない。本研究では、輝度解析ソフトを用いて ICG 血管造影による客観的な腸管 血流評価法を確立することを目的とした。【対象と方法】2007 年 2 月以降の遊離空腸 再建症例 25 例に対して行われた 30 本の ICG 血管造影映像（血流良好群 27 本、静 脈閉塞群 3 本）を対象として、輝度解析ソフトにより得られた最高輝度、最高輝度到達 時間、中間輝度到達時間 $(\mathrm{T} 1 / 2 \mathrm{max})$ 、立ち上がり時間 $(\mathrm{Tr})$ 、減衰率を臨床経過と比較 検討した。【結果】（1）静脈閉塞群で T $1 / 2 \max 、 \operatorname{Tr}$ が有意に延長していた。（2）血流 良好群のうち術後腸管壊死を来した 2 例を除いた 25 本の ICG 血管造影映像より算出 した T1/2max 基準值（mean +/- 2SD；＜10.3） は、感度 $60 \%$ 、特異度 $96 \%$ 、正診率 $90 \%$ で術中術後の血流障害（術中静脈閉塞 3 例、術後壊死 2 例）を検出し得た。【ま とめ】映像輝度解析ソフトによって算出される $\mathrm{T} 1 / 2 \mathrm{max}$ は、再建腸管の静脈還流異常 を鋭敏に判定できるパラーメーターとなりうる可能性がある。 


\section{PD02-1＼cjkstart高齢者皮膚欠損創に対する植皮術のエ夫 \\ $\sim$ Dermolipectomy の有用性}

鳴海篤志

独立行政法人国立病院機構別府医療センター 救急科

【背景】高齢者の皮膚では真皮が萎縮性で薄いため、熱傷や術後再建で分層植皮術 を行う際、採皮部の上皮化が遅れ、治療上大きな障害となることが稀ではない。1990 年池田は、皮膚と皮下組織を筋膜上で切除した後、ドラム型デルマトームを用いて薄 剥して分層植皮片を作成する新たな採皮方法として dermolipectomy を考案し、特に高 齢者熱傷の治療における有用性を報告している。【目的】高齢者植皮術における dermolipectomy の有用性を検討する。【方法】過去 8 年間に行った高齢者手術例 22 例 を対象に、手術時間、輸血量、植皮の生着率、採皮創治瘉までの期間、術後合併症、 転帰などについて検討した。【結果】手術時間は延長されたが、術中出血量は減少した。 また、本法では、採皮部は縫縮するため、確実に採皮創を閉鎖することが可能で、全 例採皮創を 1 週間で閉鎖可能で、転帰は良好だった。【結論】dermolipectomyは、 高齢者植皮術の採皮方法として、極めて有用であることが再確認された。

\section{PD02-2 大腸癌手術における創感染予防のエ夫一真皮縫合法の成績一}

横溝肇，吉松和彦，大谷泰介，大澤岳史，中山真緒，松本敦夫，塩澤俊一， 勝部隆男，成高義彦，小川健治

東京女子医科大学 東医療センター 外科

【目的】われわれは大腸癌手術時における創感染予防対策として，創閉鎖法を真皮縫 合法へ変更し良好な結果を得ている. 今回，真皮縫合法で創閉鎖を行った大腸癌手 術例の創感染の状況につき検討した。【対象・方法】2008 年 3 月から 2011 年 6 月ま でに，真皮縫合法で創閉鎖を行った術前化療例・人工肛門先行手術例を除く大腸癌 切除例 257 例を対象とした。真皮縫合法による創閉鎖は，腹膜，腹直筋腱膜を吸収 糸で縫合，持続吸引式ドレーンの皮下留置，4-0 吸収糸で真皮埋没縫合，フイルムドレッ シングとした。【結果】全対象例で創感染は 16 例（6.2\%）みられた。創感染と各臨 床病理学的因子の関連では，年齢，性別，占居部位，進行度，ileus，糖尿病合併， 術前 PS，術前 ASA 分類で差はなかったが，人工肚門造設，創分類が class IIIもしく は class IV, 緊急手術, 喫煙あり, 長時間手術, 多量出血量例で創感染が多く, 多変 量解析では人工肛門造設，創分類，喫煙が独立した因子であった。これら 3 因子い ずれかを認める 118 例では創感染は 15 例（12.7\%）みられ，3 因子を全て認めない 139 例では 1 例 $(0.7 \%)$ のみで, その 1 例は ileus による緊急手術例であった.【結語】 真皮縫合法の創感染率は $6.2 \%$ と満足できる結果であったが，全例に皮下ドレーンを留 置することには異論も多い. 人工肛門造設がなく，創分類が class II の非喫煙者は， 皮下ドレーンの省略が可能な症例と考えられ，今後の検討を要する. 
PD02-3 肝細胞癌肝切除における真皮埋没縫合 + 皮下ドレーンの有効性の検討

辻田英司，山下洋市，武石一樹，前田貴司，松山歩，筒井信一，松田裕之，

石田照佳

広島赤十字・原爆病院 外科

【対象】クリニカルパスを導入後、同一術者による 2009 年 4 月から 2011 年 8 月に行っ た肝癌切除症例 167 例。閉創に関しては、前期: 2009 年 4 月〜 2010 年 5 月は腹膜・ 筋層：モノフィラメント吸収糸による連続縫合、皮膚：3-0 ナイロンの垂直マットレス結 節縫合。後期 : 2010 年 6 月以降は皮下に閉鎖式ドレーンを留置、皮膚は真皮埋没縫 合。【方法】SSI の判定は NNIS マニュアルに従った。I）前期群 88 例と後期群 79 例、 II）SSI(-)149 例と SSI(+)18 例において、SSI の独立危険因子を検討した。【結果】I）後 期群では、前期群と比較して有意 $(\mathrm{p}<0.05)$ にSSI 発症率 $(6.3$ vs. $14.8 \%)$ が低下。手 術時間が短縮 $(239.8 \pm 90.6$ vs. $281.6 \pm 103.0$ 分) した以外に、背景因子や病理組織学 的因子に有意差なし。 II) SSI(+) 群は SSI(-) 群と比較して有意に、男性が多かった (88.9 vs. $63.1 \%)$ 。肝機能検查では血清 T.Bil 值 $(1.0 \pm 0.5$ vs. $0.7 \pm 0.3 \mathrm{mg} / \mathrm{dL}) 、 I V$ 型コラーゲ ン值 $(7.3 \pm 2.1$ vs. $5.7 \pm 1.7 \mathrm{ng} / \mathrm{mL}$ ) が高く、Child-B (16.7 vs. $4.7 \%)$ 、ASA score 3(55.6 vs. $31.5 \%)$ の症例が多かった。術後在院日数 $(31.9 \pm 34.0$ vs. $19.0 \pm 18.1$ 日 ) は有意に 延長していた。多変量解析では T.Bil、IV 型コラーゲン、閉創法が、有意な SSI の危 険因子。【まとめ】肝癌に対する肝切除後 SSI の危険因子 3 項目を明らかにした。肝 機能低下が SSI の危険因子と考えられると共に皮下ドレーン+真皮縫合による閉創法が 有意に SSI を低下させると考えられた。

\section{PD02-4 下部消化管手術における創感染予防を目的とした皮下ペンローズドレー ンの有用性の検討}

今田慎也, 能浦真吾, 山田晃正, 末田聖倫, 真貝竜史, 本告正明, 後藤邦仁, 高橋秀典, 岸健太郎, 藤原義之, 大植雅之, 矢野雅彦, 大東弘明, 石川治 大阪府立成人病センター 消化器外科

【はじめに】待機的下部消化管手術における創感染 (表層 / 深層感染)(s-SSI) は、SSI サーベイランス開始後減少したが、いまだに低率ながら発生している。更なる改善のた め、2010年6月より待機的下部消化管開腹手術症例に対して全例皮下ペンローズドレー ン (PD) の留置を開始した。【目的】PD 留置の有用性を検討する。【対象／方法】下 部消化管手術（待機的 / 開腹 / 準清潔） 282 例を対象とし、前期群（PD 非留置、 2008 年 7 月 2009 年 6 月、 $\mathrm{N}=131$ ） と後期群（PD 留置、 2010 年 6 月～ 2011 年 11 月、 $\mathrm{N}=151 ）$ の 2 群を比較検討した。【結果】後期群での PD の平均留置期間は 3.5 日であった。2 群間の背景因子の比較では、年齢/性別 / BMI/ASA/ 糖尿病歴 / 喫 煙歴 / 手術時間 / 出血量 / 人工肛門造設の有無に有意差を認めなかったが、皮下脂 肪厚が $20 \mathrm{~mm}$ 以上の症例の割合が後期群で 49.7\% (75/151) と前期群の 30.5\% (40/131) に比し有意に高率であった（P=0.001）。 s-SSI 発生率は前期群で $6.1 \%(8 / 131)$ 、後期 群で 5.3\%（8/151）であった。皮下脂肪厚 $20 \mathrm{~mm}$ 未満の症例での s-SSI 発生率は前期 群 : $2.2 \%(2 / 91)$ 、後期群 : 2.6\%（2/76）でほぼ同等であった（P=0.86）。一方、皮 下脂肪厚 $20 \mathrm{~mm}$ 以上の症例では前期群の 15.0\%(6/40)に対して、後期群は 8.0\%(6/75) と低下を認めたが、有意差は認めなかった $(\mathrm{P}=0.24)$ 。【結語】今回の検討では、皮 下脂肪厚に関わらず、皮下 PD 留置による s-SSI 低減化に対する明らかな有用性は認 めなかった。 


\section{PD02-5 内視鏡外科手術における臍の切開・形成、感染防止の工夫}

飯田敦，澤井利次，森川充洋，小練研司，村上真，廣野靖夫，五井孝憲，

片山寛次, 山口明夫

福井大学 第一外科

腹腔鏡下手術の際完全鏡視下手術で行い、カメラポートを臍内に置き、胃、脾臓、結 腸などの標本も臍を切開して取り出している。単孔式内視鏡外科手術を含め臍内切開、 形成を行っている。我々の工夫と結果を報告する。【方法】「臍切開」臍の中心より上 下 $1 \mathrm{~cm}$ にマーキングし、Pean 鉗子で臍中心を拡げて先勒刀で下縁のマーキングから臍 中心の瘏痕までの臍内下半の表皮・真皮を縦切開する。皮下剥離は行わない。臍全 体を使う場合は創が拡大し約 $3 \mathrm{~cm}$ となる。単孔式腹腔鏡下胆囊摘出術の際、10-12 mm の創の辺縁に trocar を配置する独自の Single-incision Multi-trocar 法を用いて最小の 創で気腹漏れなく安全に手術を行っている。「臍縫合・形成」腹壁切開創の確実な閉 鎖が臍の形成、瘢痕ヘルニアを予防に重要である。臍の中心の瘢痕部およびその近 傍では腹壁縫合の際に創縁の皮下を小さく左右均等にすると臍の中心が良好な形態で 窪む。5-0 Monocryl で真皮縫合する。臍を縦長に陥凹させるように臍を形成する。「感 染予防と創処置」臍清拭を術前に腹壁閉鎖時に創洗浄を行う。創にはサージカルドレー プを貼るのみ。【結果】対象 775 例で臍の創の感染例なし。術後 1 力月での外来時で の形態不満なし。【結語】臍内を直線的に皮膚切開し陥凹の形態に留意して腹壁縫合 を行うことで、各術式に有用で、縦長の陥凹を持つ美しい臍形成が可能であった。

\section{PD02-6＜wide>ストーマ閉鎖時の創閉鎖における閉鎖式持続吸引ドレーン＋真皮埋没縫 合の試み}

松本敦夫，吉松和彦，横溝肇，大谷泰介，大澤岳史，中山真緒，塩澤俊一， 勝部隆男, 成高義彦, 小川健治

東京女子医科大学東医療センター 外科

【はじめに】ストーマ閉鎖術は創感染の危険因子であり、近年、創を巾着状に縫縮する 環状皮膚縫合法の有用性が報告されている。一方、閉鎖式持続吸引ドレーン+真皮 埋没縫合による創閉鎖は下部消化管手術時の創感染予防としての有用性が報告されて いる。そこで、われわれはストーマ閉鎖時の創閉鎖に、閉鎖式持続吸引ドレーン+真 皮埋没縫合による創閉鎖法を施行しているのでその成績につき報告する。【ストーマ創 閉鎖法】ストーマを可及的に縫合閉鎖後、同部を含め紡錘状に皮膚切開し腹直筋筋 膜を十分露出した後、腸管貫通部を剥離、腸管を腹腔外に引き出しストーマの閉鎖、 あるいは腹腔内に環納し再吻合を行う。閉創は腹膜・筋膜を吸収糸で結節縫合後、温 生食にて充分に洗浄、10F blake drain を留置し、4-0 モノフィラメント吸収糸で真皮埋 没縫合する。【対象および結果】対象はストーマ創閉鎖を本閉鎖法で行った 17 例で、 年令 66（40-84）歳、男女比 $12: 5$ であった。施行した術式はハルトマン手術後の再 吻合 3 例、ループ式回腸ストーマ閉鎖 9 例、ループ式結腸ストーマ閉鎖 5 例であった。 現在までに創感染を 1 例（5.9\%）認めたが、創離開、漿液腫、ドレーンの感染は認 めていない。【結語】今後、症例集積と長期観察が必要であるが、ストーマ閉鎖術に おける閉鎖式持続吸引ドレーン+真皮埋没縫合による創閉鎖法で創感染などの合併症 減少が期待される。 
高原正和 ${ }^{1}$, 杉山晃子 ${ }^{1}$, 中野美沙 ${ }^{1}$, 中原剛士 ${ }^{1}$ ，中原真希子 ${ }^{1}$ ，内博史 ${ }^{1}$ ， 増田禎 ${ }^{1}$, 師井洋一 ${ }^{1}$, 古江増隆 ${ }^{1}$, 馬場晴久 ${ }^{2}$

1 九州大学医学研究院 皮膚科学, ${ }^{2}$ 九州大学医学研究院 救急救命センター 2005 年 1 月から 2008 年 3 月までの 3 年間に当院で加療した 0 歳から 7 歳までの小児 熱傷 35 例について報告する。35 例中、入院 20 例（男児 8 例、女児 12 例）外来 15 例（男児 9 例、女览 6 例）であり、年齢・性差、受傷原因、受傷部位を検討し、 入院を要した症例に関しては深達度、治療を集計し、検討した。その結果、平均 1.66 歳で 2 歳以下の症例が 28 例と多く、1 歳男児が 11 例で最多であった。受傷原因とし ては熱湯熱傷が $80 \%$ 以上を占め、入院を要した症例は全例が熱湯熱傷であり、上方 から熱湯をかぶる症例がほとんどであった。それに伴って、受傷部位は顔面から前胸 部を中心に受傷し、同時にその部位の深達度が深い傾向にあつた。局所治療は basic fibroblast growth factor (bFGF) スプレーを用いた wet dressing を行い、深達度が 2 度 浅層までであった症例は 1 週間前後で完全上皮化を認め、受傷時 2 度深層と判断され た症例においては 12 例中 11 例が 3 週間で $90 \%$ 以上上皮化を認めた。外科的処置を 要した症例は 2 例のみであった。このような臨床経過から、小巟の 2 度以上の熱傷に 対して早期の bFGF スプレーの使用と消毒薬や抗菌外用薬を最小限におさえた wet dressing が効果的な治療法であることが示された。

\section{PD02-8＼cjkstart当科における傷の治し方のエ夫}

東貴寛，江口大彦，枝川愛，伊藤心二，江頭明典，内山秀昭，川中博文， 立石雅宏，是永大輔，竹中賢治

福岡市立病院機構福岡市民病院

当科（血管外科）における創傷管理の実際とそれを裏づけるエビデンスを述べ、最後 に感染創、開放創に対する創傷処置の実際を写真で供覧したい。当科では一次縫合 創に対するドレッシング材にこだわりはない。ガーゼの場合もあればパッド付ポリウレタン フィルム・カットバンの場合もある。実際、従来の消毒とガーゼといら方法と比較して一 次縫合創に対する modern dressing の優位性は証明されていない。シャワー浴は、創 に問題がなければ術後 2 日目からは可としている。これは一次縫合創の上皮化は 12 時間から 48 時間で完成し外界に対するバリアー機能をといらエビデンスに基づく。ただ し創の適合がわるく、浸出液や出血が夕られる場合には延期する場合がある。ちなみ に術後早期のシャワー浴は、看護師のマンパワーや患者の離床度、またはドレーンの 有無などによって、現実的には困難な場合がある。（当科ではバイパス手術や腹部大 動脈瘤手術後にドレーンは留置していないが）感染創（足壊疽の切断後や感染性動 脈瘤切除後など）に対しては、基本的に開放創として污染の重症度と感染再燃時の危 険度に応じて閉鎖持続陰圧療法や創内持続洗浄陰圧療法などを行っている。この際、 洗浄の方法とタイミングが不適切であった場合、感染を拡大させる場合があることに注意 しなければならない。この分野での創傷管理におけるエビデンスはまだ蓄積がないため、 施設間の管理方法には差があると考えられる。 
PD03-1 QOL からみた迷走神経温存 J型空腸囊間置噴門側胃切除術について

富田凉一 ${ }^{1}$, 藤崎滋 ${ }^{2}$, 杉藤公信 ${ }^{3}$, 池田太郎 ${ }^{3}$, 櫻井健 ${ }^{3}$, 越永従道 ${ }^{3}$, 柴田昌彦 ${ }^{4}$

${ }^{1}$ 日本歯科大学 生命歯学部 外科学講座, ${ }^{2}$ 藤崎病院 外科, ${ }^{3}$ 日本大学 医学部 外科系小览・乳腺内分泌外科学分野, ${ }^{4}$ 福島県立医科大学 医学部 腫瘍生体治 療学講座

【目的】迷走神経 $(\mathrm{VN})$ - 下部食道括約筋 (LES) 非温存の胃全摘兼空腸間置術 (A 群) や噴門側胃切除術 (B 群) では種々の胃切除後障害を認める。その予防にVN・LES 温存 $\mathrm{J}$ 型空腸囊間置噴門側胃切除術 (C 群) を行っているので有用性を検討した。【方 法】A 群 20 例 (男 15 例、女 5 例、平均 61.1 歳)、B 群 16 例 (男 11 例、女 5 例、 平均 65.3 歳)、C 群 10 例 (男 6 例、女 4 例、平均 61.9 歳) での術後 QOL と病態生 理について、対照 D 群 20 例 (男 16 例、女 4 例、平均 60.8 歳) を用い比較検討した。 【成績】1）直接問診法：早期ダンピング症候群はA 群 $20.0 \%$ 、 B 群 $18.8 \%$ 、 C 群 10.0\%で C 群が少なかった。逆流性食道炎症状はA 群 $35.0 \%$ 、B 群 $56.3 \%$ 、C 群 0\%、 1 回食事摂取量術前比較 $80 \%$ 以上はA 群 $20.0 \%$ 、B 群 $37.5 \%$ 、C 群 $80.0 \%$ で有意 に C 群が A、B 群より良好だった（それぞれ $\mathrm{p}<0.05$ )。2) 下部食道\%時間 $\mathrm{pH}>7: \mathrm{A}$

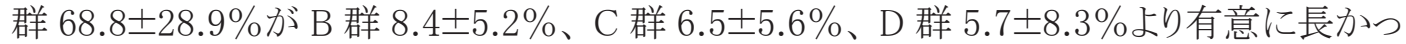
た (それぞれ $\mathrm{p}<0.001$ )。下部食道 $\%$ 時間 $\mathrm{pH}<4: \mathrm{B}$ 群 $22.1 \pm 9.7 \%$ が A 群 $1.4 \pm 2.3 \%$ 、

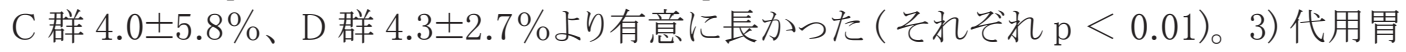
残存率 50\%時間 :C 群 $64.7 \pm 11.3$ 分は D 群 52.3土9.5 分と差がなく有意に A 群 $28.6 \pm$ 9.4 分より長く、B 群 88.8土18.6 分より短かった（それぞれ $\mathrm{p}<0.01$ )。【結論】C 群は A、 B 群より早期ダンピン症候群、逆流性食道炎、小胃症が少なかった。また、下部食道 への酸とアルカリ逆流が少なく、代用胃貯留機能も良好であった。

\section{PD03-2＼cjkstart早期胃癌に対する HALS-DG と LADG との比較}

矢島浩 ${ }^{1}$, 矢永勝彦 ${ }^{2}$, 高橋直人 ${ }^{1}$, 坪井一人 ${ }^{1}$, 藤崎宗春 ${ }^{1}$, 小林進 ${ }^{1}$, 柳澤暁 $^{1}$, 小村伸朗 ${ }^{2}$, 大木隆生 ${ }^{2}$

${ }^{1}$ 東京慈恵会医科大学 柏病院 外科, ${ }^{2}$ 東京慈恵会医科大学 外科学講座

【はじめに】胃癌患者の QOL 向上を目的に当科では，早期胃癌に対する鏡視下手術 として当初 HALS-DGを，その後 LADG を導入した。今回われわれは，両術式の治療 成績を比較し，それぞれの有用性を検討した。【対象と方法】早期胃癌に対し当大学 附属柏病院外科で，2005 年 12 月から 2009 年 1 月までに用手 - 腹腔鏡補助下幽門 側胃切除術，Billroth I 法再建を施行した 33 例 (HALS-DG 群) と 2009 年 4 月から 2012 年 12 月までに腹腔鏡補助下幽門側胃切除術, Billroth I 法再建を施行した 44 例 (LADG 群) を対象とした. HALS-DG は $7 \mathrm{~cm}$ の上腹部正中切開をおき, $5 \mathrm{~mm}$ のトロカー 1 本， $12 \mathrm{~mm}$ のトロカー 2 本の 3 ポートで施行した. LADG は $5 \mathrm{~mm}$ のトロカー 2 本, $12 \mathrm{~mm}$ のトロカー 3 本の 5 ポートで施行し, 胃の切離と再建のために $5 \mathrm{~cm}$ の上腹部正 中切開をおいた.【結果】両群間で年齢, 性別, BMI, 出血量, 術後在院日数に有 意差を認めなかった。手術時間は HALS-DG 群が有意に短かった $(\mathrm{p}<0.01)$. リンパ 節郭清個数はLADG 群が有意に多かった $(\mathrm{p}<0.01)$. 両群とも再発を認めていない、【結 論】HALS-DG は LADG と比較し，整容性に劣るが手術時間は短く低侵襲であつた。 予後への影響はないと考えられるが，リンパ節郭清個数は少なかった。在院日数の点 で術後早期 QOL は同等であった。 


\section{PD03-3 13C 空腸吸収能検査・RI 法による排出能検査からみた空腸囊付加}

Roux-en-Y 再建の意義

柏原秀也, 島田光生, 栗田信浩, 岩田貴, 佐藤宏彦, 西岡将規, 森本慎也, 吉川幸造, 宮谷知彦, 高須千絵

徳島大学 消化器・移植外科

目的）胃全摘術後の再建に空腸囊を付加することにより良好な排出能が得られ QOL が 改善されるとの報告がある。我々は 99mTc-DTPAを用いた RI 法にて空腸囊付加 Roux-en-Y 再建例で空腸囊からの排出遅延を報告したが、今回 13C を用いた空腸吸 収能検査にて興味ある知見を得たので報告する。対象・方法）検討 1 : 胃全摘後空 腸囊付加 Roux-en-Y 再建後 $1 \sim 1.5$ 年経過例 (pouch 群: n=12) と健常 volunteer (Control 群 :n=4) に 99mTc-DTPA を投与し、RI 法にて排出能を比較検討。検討 2 ： pouch 群 ( $4 \sim 5$ 年経過 : n=11) と Roux-en Y 再建 $(\mathrm{R}-\mathrm{Y}$ 群 : n=5)、Control 群 $(\mathrm{n}=4)$ に $13 \mathrm{C}$-acetate $100 \mathrm{mg}$ 老投与し、赤外分光分析にて呼気中 $\mathrm{CO}_{2}$ を測定。結果）検討 1 : Control 群 T1/2 は 44 分に対し pouch 群では 9 例 (75.0\%) で T1/2 算出不可な程度に 空腸囊排出が遅延。検査後停滞による再手術、肺炎による死亡を各 1 例認めた。検 討 2 : breath-Tmax は pouch 群 19.0 分、R-Y 群 11.7 分で差なく、Control 群 42.5 分 と比べ両群とも有意に短縮。各測定時の呼気中 $\mathrm{CO}_{2}$ 存在率は R-Y 群と Control 群で 差を認めず、 R-Y 群は 60 分以降 Control 群と差のない值まで低下したが、pouch 群は 135 分まで有意に高值であり排出遅延が遷延した。結論）胃全摘後 Roux-en-Y 再建 に空腸囊を付加することによる advantage は明らかでなかった。

\section{PD03-4 大腸癌術後腹壁瘢痕ヘルニアの発生危険因子の検討}

中山真緒, 吉松和彦, 横溝肇, 大谷泰介, 大澤岳史, 松本敦夫, 塩澤俊一, 勝部隆男, 成高義彦, 小川健治

東京女子医科大学東医療センター 外科

【はじめに】術後の腹壁瘢痕ヘルニアは創合併症のうち, 最も長期間にわたり患者の QOL を損ない, その修復には手術を必要とするが, 詳細な報告は少ない. 今回, 当 科における大腸癌術後の腹壁瘢痕ヘルニアの発生状況および発生の危険因子につい て検討した.【対象・方法】対象は 2006 年 10 月から 2009 年 7 月までの大腸癌開腹 手術症例のうち, 術後 1 年以上経過観察した 167 例である. 閉腹時の筋膜腹膜閉鎖 は全例 1 号の編み糸吸収糸による結節縫合で行った。腹壁㓔痕ヘルニアは腹部診察 所見と腹部 CT 検查所見で診断した。ヘルニア発生に関連する臨床病理学的因子を抽 出, 多変量解析で危険因子を検討した。【結果】腹壁㓔痕ヘルニアは 27 例 $(16.2 \%)$ に発生した. 臨床病理学的因子のうち, 年齢, 糖尿病, 肺機能障害, Stage, 術中污 染の有無，創感染の有無，皮膚閉鎖法と関連はなかったが，女性，BMI 25 以上，左 側大腸癌, 血清アルブミン值 3.5 未満の症例に腹壁瘃痕ヘルニアの発生率が高かった $(\mathrm{p}=$ 各 $0.0051,0.0437,0.0052,0.0287)$. 多変量解析では 4 因子の odds 比は各 4.528, 4.364，9.593，4.152 ですべてが独立した因子であった ( $\mathrm{p}=$ 各 0.0014，0.0069，0.0004, 0.0094).【結語】大腸癌術後の腹壁痸痕へルニアの発生は比較的高率であった. 腹 壁㓔痕ヘルニアの発生には, 皮下脂肪量, 下腹部切開, 低栄養が関与寸ることが示 唆された. 


\section{PD03-5}

態と QOL

藤崎滋 $^{1,2}$, 高山忠利 ${ }^{2}$, 高階幹 ${ }^{1}$, 富田凉 ${ }^{3}$

${ }^{1}$ 藤崎病院 外科, ${ }^{2}$ 日本大学 医学部 消化器外科, ${ }^{3}$ 日本歯科大学 外科 十二指腸乳頭部癌の膵頭十二指腸切除後の長期生存例の遠隔期の病態を検討し、 QOL を考察した。対象は術後 $10^{\sim} 16$ 年経過し、現在無再発生存中の十二指腸乳頭 部癌 5 例を対象とした。50 歳から 68 歳 (中央值 65 歳)、男女比は $3: 2 。$ 術式は PPPD が 4 例、PD が 1 例。Child 変法を基本とした。いずれも術前に糖尿病や慢性膵 炎の合併はなく、術後の早期合併症 (膵液瘻など ) はなかった。体重の変化、脂肪肝、 糖尿病の合併症の有無、血算・生化学検査・HbA1c を検討項目とした。切除術後 1 年以降の症状・検査成績を経時的に比較検討した。（結果）術後 1 年以降に下痢、 便性状の悪化、胆管炎を繰り返す症例はなかった。遠隔期の体重は術後 1 年と比して $12 \%$ 減が 1 例 ( 遠隔期に糖尿病合併例 )、 $7.6 \%$ 増が 1 例、他は $5 \%$ 以内の変化。5 例 とも術後 1 年から軽度の脂肪肝あり (CT 值; $30 \mathrm{HU}$ 以下はなし)。軽度の肝障害 (AST,ALT <60) が 1 例あったが、脂肪肝・肝障害は経時的に進行しなかった。 TP,Alb 值はい ずれも正常範囲で推移。2 例において TG,T-chol の上昇あり。 Hb は 1 例のみが軽度 低值であった。HbA1c 值は術後 4 年以降に 2 例において 8.0 および 6.1 まで上昇する も、食事運動療法で改善した。(結語) 軽度の脂肪肝は比較的早期にみられたが、遠 隔期に進行しなかった。耐糖能異常は遠隔期に 2 例に認めたが改善した。栄養障害 などの深刻な遠隔期の合併症はみられず、十二指腸乳頭部癌の膵頭十二指腸切除術 後の遠隔期の QOL は保たれていた。

\section{PD03-6 BI 法 vsRY 法に関する多施設共同無作為試験 $-\mathrm{QOL}$ 及び術後機能 障害のアンケート調査一}

瀧口修司 $^{1}$ ，山本和義 ${ }^{5}$ ，平尾素宏 ${ }^{5}$ ，今村博司 ${ }^{2}$ ，藤田淳也 ${ }^{3}$ ，木村豊 ${ }^{4}$,

黒川幸典 ${ }^{1}$, 高橋剛 ${ }^{1}$, 山崎誠 ${ }^{1}$, 宮田博志 ${ }^{1}$, 中島清一 ${ }^{1}$, 森正樹 ${ }^{1}$,

土岐祐一郎 ${ }^{1}$

${ }^{1}$ 大阪大学大学院消化器外科学, ${ }^{2}$ 市立堺病院, ${ }^{3}$ 市立豊中病院, ${ }^{4} \mathrm{NTT}$ 西日本大 阪病院， ${ }^{5}$ 大阪医療センター

【背景】胃癌に対する幽門側胃切除後再建法としての Billroth-I(B-I) 法と Roux-enY(RY) 法において提供すべき手術術式決定のため、術後 1 年の体重減少率を Primary end point として無作為比較試験を多施設（大阪大学消化器外科共同研究会上部疾患分 科会：23 施設）共同前向き試験で実施した。【対象と方法】QOL 及び術後障害に関 しては郵送法によるアンケート調査を実施した。全症例が登録を終了した 3 か月後に一 斉にアンケートを郵送し回収した。QOL 調査票としては EORTC-QLQ-C30 ver 3.0 日 本語版、術後障害の調査票に DAGUS20 を使用した。【結果】 329 例のらち 281 例か ら回答を得た（B- I 群 137 例、R-Y 群 144 例、回収率 85.9\%)。Overall の検討では、 術後 2 年以上経過した症例で、それ以前と比較して有意な術後機能障害の軽減が見ら れた。群別では、術後機能障害評価全体及び QOL 総合評価としては有意差を認めな かった。サブクラス解析で Sympton scale の Dyspnea でスコアに有意な差が見られ RY 群で良好であった。しかしながら、その他の指標では有意差は見られず平均スコアも僅 差であった。DAUGS20 の解析では、逆流症状において B-I 群で有意に悪かったが、 その他、有意な差のある術後障害は認めなかった。【結語】胃癌幽門側胃切除後再建 に関する QOL と術後機能障害のアンケート調査の結果 RY 群の早期に術後障害が見ら れる傾向がある一方、逆流などの症状はBI で強く見られた。 


\section{PD04-1＼cjkstart分子標的薬の皮膚障害とその対策}

中原剛士 , 師井洋一, 高原正和, 古江増隆

九州大学大学院 医学研究院 皮膚科学

近年癌薬物治療において、分子標的薬の出現により大きな進展が見られるようになって きている。分子標的薬は癌細胞の増殖や転移・浸潤に関わる遺伝子や蛋白を特異的 に標的とするため、骨髄抑制や腎障害などの重篤な全身の有害反応発現率は低い。し かし今まで見られなかった新しい皮膚障害を呈することが特徵的である。特にゲフィチニ ブ、エルロチニブ、セツキシマブなどの上皮細胞成長因子受容体（EGFR）阻害剂に よるざ瘡様皮疹や乾燥肌、爪囲炎はその代表例であり，それらの皮膚障害に対する対 応や考え方も大きく変化している。すなわちいくつかの分子標的薬では皮膚症状と疾患 に対する有効性の相関が明らかになり、皮膚症状が効果の指標となることが示唆されて いる。したがって皮膚障害は必ずしも有害な副作用ではなく薬剤の効果発現の指標で あり、さらには治療効果のマーカーとなり得ることを考慮すると、予防や治療による皮膚 障害の症状軽減・緩和が分子標的薬の服用継続期間や治療効果に直結することが考 えられる。少なくとも皮膚障害が原因となって治療が中止されることなく、対症的に皮膚 症状を制御しながら治療を安全に続けられるよう、主治医、皮膚科医とともに、看護師 によるスキンケア指導，薬剤師による有害事象についての啓発など医療スタッフ間の協 力が必要となる。今回は分子標的薬に特徵的な皮膚障害とその予防、治療について概 説する。

\section{PD04-2 当科における Panitumumab による皮膚障害への対応と工夫}

烟泰司 ${ }^{1}$ ，倉知貴志郎 ${ }^{2}$ ，早石祥子 ${ }^{2}$ ，田中文 ${ }^{2}$, 波多豪 ${ }^{1}$, 藤野志季 ${ }^{1}$, 三宅正和 $^{1}$, 野田剛広 ${ }^{1}$, 川西賢秀 ${ }^{1}$, 森田俊治 ${ }^{1}$, 藤田純也 ${ }^{1}$, 岩澤卓 ${ }^{1}$, 赤木謙三 $^{1}$, 堂野恵三 ${ }^{1}$, 北田昌之 ${ }^{1}$

1 市立豊中病院 消化器外科, ${ }^{2}$ 市立豊中病院 皮膚科

【はじめに】進行再発大腸癌において使用されている Panitumumab（以下 Pmab）は EGFR をターゲットとした分子標的薬剤である。皮膚障害が多く見られ、効果と相関が あるとの報告もある。ゆえに皮膚障害を緩和し患者の QOL と治療効果を担保することは 重要と考えられる。当科では先行して使用可能となった Cetuximab での経験を生かし、 下部消化管外科医、皮膚科医、癌化学療法認定看護師のチームでマニュアルと患者 向けパンフレットを作成、皮膚障害のマネージメントを行った。導入前にパンフレットを 用いてのオリエンテーションでセルフケアの重要性を説明し、予防的に保湿剤を導入、 発疹の出現時より積極的にステロイド剂を使用してもらった。症状によってステロイドの 変更、内服を開始、困難例や外科的処置を有すると判断した時は外科の紹介なく皮膚 科医受診が出来る体制とした。【結果】現時点で 27 例に Pmab が投与されていた。 line 別では 1st line 2 例、2nd line 3 例、3rd line 以降は 22 例であった。3rd line 以降 症例での奏功率は 14.3\%、腫瘍制御率は $64.3 \%$ であつた。皮膚毒性に関して Grade2 が 22.2\%、Grade3 が 8.3\% で Grade4 以上は認めなかった。【まとめ】自施設での比較 はないものの STEPP 試験での予防投与群と遜色ない結果が得られており、積極的なマ ネージメントの効果はありと思われた。皮膚障害に対しては患者への啓蒙とチームで対 応するのが重要と考えられた。 


\section{PD04-3 大腸癌患者における抗 EGFR 抗体使用時の皮膚障害アセスメントの重要}

性

玉川浩司 ${ }^{1}$, 松田宙 ${ }^{1}$, 青野豊一 ${ }^{1}$, 武田伸一 ${ }^{1}$, 吉田洋 ${ }^{1}$, 野村昌哉 ${ }^{1}$,

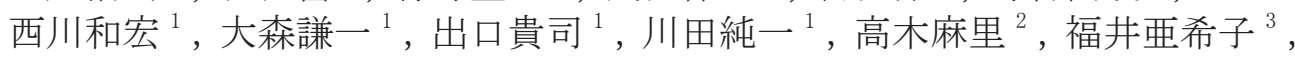
岩瀬和裕 ${ }^{1}$, 田中康博 ${ }^{1}$

1 大阪府立急性期総合医療センター 外科, ${ }^{2}$ 大阪府立急性期総合医療センター 薬局, ${ }^{3}$ 大阪府立急性期総合医療センター 化学療法室

【背景】進行再発大腸癌に対して抗 EGFR 抗体 (cetuximab, panitumumab) を使用する 際、皮膚障害のマネージメントは治療の継続性にかかわる問題である。【方法】2009 〜 11 年に当施設で抗 EGFR 抗体を使用した大腸癌患者を対象しした。2011 年 1 月か らは副作用チェックシートを用いて自覚・他覚的評価を行っている。対象患者を副作用 チェックシート導入前 (2009-2010：33 例) と導入後 (2011：11 例)に 2 分し、皮膚障 害の状態とマネージメントの実情を後ろ向きに解析した。【成績】抗 EGFR 抗体使用患 者において CTCAE グレード 1/2/3 の皮膚障害の発現頻度は $91 / 50 / 18 \%$ であった。副 作用チェックシート導入前／後における皮膚障害の出現頻度は不変であつたが、グレー ド 3 に関しては出現頻度が低下傾向にあった。なお 3 例を除き、2 次治療以降に抗 EGFR 抗体を使用しているため、抗 EGFR 抗体導入時にすでに手足症候群などの皮膚 障害が生じている症例が 33\% 存在し、これらは抗 EGFR 抗体導入によりさらに皮膚障害 が増悪する傾向を認めた。副作用チェックシート導入後は治療基準の統一もはかられ、 グレード 1 ～ 2 にはステロイド外用、ミノマイシン内服を、グレード 3 は皮膚科受診とした。 【結語】抗 EGFR 抗体使用時には皮膚症状の適切なアセスメントは予防、治療になら ぶキーファクターの一つであり、前治療における手足症候群や併用薬による皮膚障害の アセスメント、マネージメントも重要であると考える。

\section{PD04-4 抗 EGFR 抗体薬使用時の皮膚障害マネジメントー当院での経験}

深澤貴子, 宇野彰晋, 村上智洋, 片橋一人, 神藤修, 松本圭五, 伊藤靖,

落合秀人，鈴木昌八，北村宏

磐田市立総合病院 消化器外科

【目的】進行・再発大腸癌に対する分子標的治療薬である抗 EGFR 抗体薬では皮膚 障害は必発の副作用であり, 患者の身体的のみならず社会的苦痛にも影響するため, 適切なマネジメントが不可欠である. 当院での使用例について検討した.【方法】 2010 年 1 月から 2012 年 1 月までの 2 年間に当院でセツキシマブ ( 以下 C-mab )またはパ ニツムマブ (P-mab)を用いて治療した 14 例について, 診療情報録より遡及的に検討. 【結果】年齢中央值 65 歳 (39-83) 男性 8 女性 6. 原発部位は右側結腸 5, 左側結腸 5, 直腸 4. 初発時病期は StageII 1 例, StageIIIa 2 例, StageIIIb 2 例, StageIV 10 例 . 皮膚 障害は 12 例 (85.7\%) で発生したが, Grade3 以上は認めず皮膚障害による投与中止例 はなかった。全症例に対し外来化学療法室で看護師, 薬剤師によるスキンケア指導, 皮 膚障害についての情報提供が行われ, 予防的外用薬投与は 7 例, 予防的内服薬投与 は 4 例に施行されていた.【考察】症例数は少ないものの, 抗 EGFR 抗体薬の使用は 外来化学療法室でのコメディカルによる指導および予防的投与の下安全に施行可能で あった.C-mab 併用レジメン 25 コースの後 P-mab 併用レジメン 10 コースを継続し SD を 維持している症例を経験しており, 抗腫瘍効果が維持されれば適切なマネジメントにより 長期投与も可能と考える. 


\section{PD04-5 当科における Panitumumab 使用症例に対する有効性と問題点}

手塚徹, 幸田圭史, 安田秀喜, 鈴木正人, 山崎将人, 小杉千弘, 村田聡一郎,

今井健一郎, 平野敦史, 岡野美々, 白神梨沙, 板垣亮平

帝京大学ちば総合医療センター外科

過去 14 ヶ月間に進行再発大腸癌に対し Panitumumab（以下 P-mab）を投与した 19 例を対象とし, 投与状況および奏効率, 有害事象につき供覽し考察を加えた。【成績】1） 投与 line : 1st line 3 例（いずれも Bevacizumab 投与後根治術を施行しその後再発）, 2nd line 8 例, 3rd line 6 例, 4th line 2 例であった. 2) 投与レジメン: FOLFIRI+Pmab 13 例, mFOLFOX7+ P-mab 4 例, 単剂投与 2 例であった. 3) 前治療の分子標 的薬: Bevacizumab 16 例, Cetuximab 3 例であった. 4) 移行理由：PD 12 例, 根治 術後再発 3 例, 有害事象 4 例（肝性昏睡，不正性器出血，血栓症，静脈瘤破裂） であった. 5) KRAS type：wild 18 例， mutation 1 例（13codon+）であった. 6) 効果 判定：PR 1 例, SD 2 例, PD 12 例, 判定不可 4 例で奏効率 $5.3 \%$, 腫瘍制御率 15.8\%であった。 6) 有害事象：皮膚障害は 7 例（Grade1：3 例, Grade3：4 例）, infusion reaction 1 例, 低 $M g$ 血症 1 例, 頑固なめまい 1 例であった.【考察】第 3 の 分子標的薬である Panitumumab の治療成績は，全例既治療例であったこともあり良好と

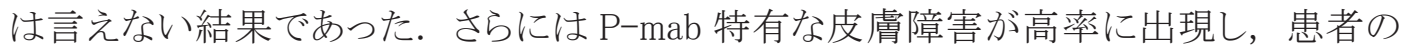
QOL を著しく低下させひいては投薬コンプライアンスを低下させる可能性があるので, 外来医のみならず皮膚科医や看護師との連携により細やかな経過観察が必要とされる.

\section{PD05-1＼cjkstart術後鎮痛サービスチームによる術後鎮痛}

若崎るみ枝, 櫻井静佳, 柴田志保, 及川美帆里, 比嘉和夫

福岡大学 医学部 麻酔科学

十分な術後痛管理は、早期離床、早期回復を可能にして、術後合併症を予防寸る。 自己調節鎮痛（patient-controlled analgesia：PCA）は、患者が痛みを感じてから鎮 痛までの時間が短縮するので、現在 PCA が広く用いられている。しかし、偶発症や鎮 痛が不十分になることがある。偶発症や鎮痛が不十分な症例を早期に発見し、安全に 十分な術後鎮痛を可能にするには、チームによる術後痛管理が必要である。

福岡大学では、麻酔科医を中心とした術後鎮痛サービスチームによる術後痛管理を行っ ている。強い痛みが起こる可能性が高い手術後には、機械式 PCA ポンプによる術後 鎮痛が必要である。

開胸手術、上腹部開腹手術患者に機械式 PCA ポンプによる硬膜外鎮痛を行っている。 硬膜外鎮痛のできない患者と脊椎手術、心臓外科手術、耳鼻科手術に機械式 PCA ポ ンプによる静脈内鎮痛を行っている。下腹部手術、整形外科手術患者にはディズポー ザブル携帯型持続注入器を使用している。

麻酔科医による回診を 1 日 2 回行い、痛みの診察、鎮痛薬の調節や補充、副作用、 偶発症の確認と治療を行う。痛みの程度は「術後痛管理シート」に視覚的評価尺度 （VAS）で記録する。機械式 PCA ポンプを使用時は、看護師に鎮痛不良時や機械トラ ブル時の対応を指示している。

今回、福岡大学で行っている術後鎮痛サービスによる術後痛管理について紹介寸る。 


\section{PD05-2 生体肝移植ドナ一患者の術後疼痛管理 一フェンタニル ivPCA}

村上雅子，大庭由宇吾，塩川浩輝，外須美夫

九州大学 麻酔蘇生科

より良い術後経過を提供するためには的確な術後急性疼痛管理が重要であることは論 をまたない。我々は生体肝移植ドナーの術後疼痛管理をフェンタニルによる静脈内自 己調節鎮痛法（intra-venous Patient-Controlled Analgesia: ivPCA）で行って来たが、 鎮痛効果について検討を行った。【対象】平成 23 年 5 月から平成 24 年 2 月の間に九 州大学病院手術室で行われた生体肝移植ドナー 20 例【方法】麻酔は空気、酸素、 イソフルレン、レミフェンタニルで行った。術終了 2 時間前からフェンタニルのローディン グ $(0.4 \mu \mathrm{g} / \mathrm{kg} / \mathrm{h})$ を行い終了直後 PCA を開始した。PCA は電動式ポンプのカセットに 生理食塩水で希釈したフェンタニル溶液 $(10 \mu \mathrm{g} / \mathrm{ml})$ を充填して行った。PCAの初動メ ニューは持続投与量 $0.4 \mu \mathrm{g} / \mathrm{kg} / \mathrm{h}$ 、ボーラス量 $0.4 \mu \mathrm{g} / \mathrm{kg}$ 、ロックアウト時間 10 分、時間 有効回数 5 回を基本とした。術後はVAS 30 以下を目標にメニューを調節した。【結果】 PCA を実施した期間は OPODから 3PODであった。フェンタニル持続投与量は

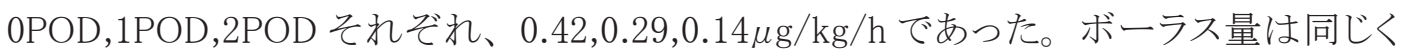
$0.39,0.29,0.23 \mu \mathrm{g} / \mathrm{kg}$ であった。フェンタニル一日投与量は $730.0 \mu \mathrm{g}(12.5 \mu / \mathrm{kg}), 549.1 \mu$ $\mathrm{g}(8.8 \mu / \mathrm{kg}) 、 240 \mu \mathrm{g}(3.6 \mu / \mathrm{kg})$ であった。VAS は 17.4 から 22.2 であった。【結論】フェ ンタニル ivPCA は持続投与量 $0.4 \mu \mathrm{g} / \mathrm{kg} / \mathrm{h}$ 、ボーラス量 $0.4 \mu \mathrm{g} / \mathrm{kg}$ を初動メニューとして 開始し経日的に投与量を減じてVAS30 に緩和することができた。

\section{PD05-3 呼吸器外科手術後における助間神経痛に対するプレガバリンの治療効 果に関する検討}

庄司文裕，桂正和，鹿田康紀，竹尾貞徳

国立病院機構 九州医療センター 呼吸器センター外科部門

【背景】呼吸器外科手術後に生じる肋間神経痛は患者の ADL 低下を招き、日常生活 の QOL 低下に繋がる。本邦においてもプレガバリンが神経障害性疼痛に対する薬物 治療の新たな選択肢として加わった。目的】呼吸器外科術後肋間神経痛に対するプ レガバリンの有効性、安全性を検討寸る。【対象】 2011 年 10 月から 2012 年 1 月に当 科にて開胸下手術を行い、術後肋間神経痛に対してNSAIDs が無効であった 18 症例。 対象の内訳は、年齢：平均 66 歳 (27-85)、性別：男性 / 女性 $=13 / 5$ 。【術後疼痛 管理】術後 2 日目まで硬膜外カテーテル留置、術後 1 日目より NSAIDs 内服開始。【評 価方法】自覚症状：患者自身の状態変化をプレガバリン内服前と比較して評価、疼痛 スコア：NRSを用いてプレガバリン内服 7 日目及び 28 日目に評価。【結果】手術日及 び胸腔ドレーン抜去日からプレガバリン投与までの平均期間はそれぞれ 6.9 日及び 1.8 日であり、プレガバリン 1 日投与量は平均 258mg（150-300）であった。自覚症状は 改善 / 不変 / 悪化 / 評価不能 $=13 / 3 / 0 / 2$ であり、プレガバリン内服前疼痛スコア 10 に対して内服後 7 日目及び 28 日目ともに有意に疼痛スコアの低下を認めた（内服後 7 日目 : $5.8 \pm 0.7 、 \mathrm{p}<0.0001$ 、内服後 28 日目 $: 4.1 \pm 0.9 、 \mathrm{p}=0.0001)$ 。副作用は眩量 及び幻覚を各 1 例ずつ認め、内服後 2 日目に中止となった。【結語】プレガバリンは 呼吸器外科手術後における肋間神経痛に対寸る薬物治療の有効な選択肢となり得るこ とが示唆された。 


\section{PD05-4}

泉董

福岡市立こども病院・感染症センター 麻酔科

かつて、新生児、乳児、小児は痛みを感じにくいと考えられており、この年代の患者に 対する術後鎮痛は長い間注目されてこなかった。近年の研究により、小児も成人同様 に痛みを感じ、疼痛による生理学的・精神的有害反応もまた成人同様に生じることが知 られてきた。成人における術後鎮痛は数十年にわたり目覚ましい発達を遂げているが、 世界的に小児の術後鎮痛が注目され始めたのは比較的最近で、小坚術後鎮痛はいま だ発展途上の領域といえる。小児医療の発達による処置や手術の複雑化、高侵襲化 に伴い、小児術後鎮痛への理解は今後ますます重要になってくると考えられる。

小児の疼痛コントロールでは、知っておくべき重要な要素がある。成人で行われるよう な疼痛の評価がしばしば行えないこと、年齢によって薬物の代謝能力や薬理効果が変 化すること、薬物療法において小巟に特有の副作用が存在すること、硬膜外チューブ の挿入や維持管理が成人より難しいこと、患児の痛みが家族、とりわけ両親にも多大な 苦痛を与えることなどである。

今回のシンポジウムでは、上述したような小児術後鎮痛の特殊性について概説し、実 際の鎮痛法として、硬膜外鎮痛法およびオピオイドを中心とした自己調節鎮痛法 (Patient controlled analgesia: PCA) について福岡市立こども病院における実践を交えて解説す る。

\section{PD06-1 最近の周術期管理における輸液療法の進歩}

竹山正治，松永明，今林徹，上村裕一

鹿児島大学 医学部 麻酔・蘇生学教室

周術期輸液療法の進歩は、1950 年代後半から 1960 年代前半に Moore と Shires らが 異なる輸液の考え方が示したことに始まり、今日まで最適な輸液の量および質に関する 多くの研究が行われてきたが、未だ決着を見てない。しかし、近年晶質液を主とした大 量輸液療法が消化管縫合不全や消化管機能低下などの原因となりうると認識されるよう になり、その代わりに、血管内容量の保持や末梢循環維持を目的に膠質液を主とした 制限輸液療法が注目されてきた。さらに、血圧や尿量などの古典的な指標に加えて、 低侵襲血行動態モニタから得られる指標に基づいて、最適な循環を維持するために必 要な輸液は積極的に行う輸液適正化（fluid optimization）といら概念が提唱されてきた。 今回、このような転換点を迎えている周術期輸液管理、および制限輸液療法や輸液適 正化で積極的に使用される人工膠質液について解説する。 


\section{PD06-2ＳVVによる輸液反応性の評価}

演田高太郎

産業医科大学 麻酔科学教室

2008 年、英国で外科手術患者の輸液管理についてのガイドライン「GIFTASUP」が策 定された。GIFTASUP では周術期の循環血液量不足は flow-based technique によって 診断することを推奨している。すなわち、血圧や心拍数からでは判断できない組織の低 灌流状態を心拍出量モニターによって明らかにし、輸液による治療を行うことの重要性 を強調している。心拍出量を増加させる手段として輸液負荷があり、輸液負荷によって 心拍出量が増加する状態を輸液反応性があるという。輸液反応性があるということは Frank-Starling（FS）曲線の傾きが大きいところに位置することを意味する。輸液反応 性を自動的かつ連続的に評価する指標として一回拍出量の呼吸性変動（SVV：stroke volume variation）がある。この呼吸性変動は、胸腔内圧変化による左室前負荷の変化 が原因となっている。SVV は FS 曲線の傾きが大きい位置つまり輸液反応性が大きい状 態で曊著となる。SVV が $10 〜 13 \%$ 前後以上になったときに輸液反応性があることが多 いとされている。拡大手術では術後嘔気・嘔吐、術後イレウス、消化管縫合不全など の術後合併症を減らすために過剩輸液を避けると同時に輸液適正化を達成するため低 侵襲な心拍出量モニターを使用し、1 回拍出量および輸液反応性を評価しながら輸液 管理を行うことが推奨される。

\section{PD06-3小児における周術期輸液戦略}

吉野淳, 泉薰, 自見宣郎, 住吉理絵子, 水野圭一郎

福岡市立こども病院・感染症センター 麻酔科

周術期における輸液管理は外科医と麻酔科医に与えられた共通の課題である。小児は 成人と比較して身体構成水分が多く、特に新生児では約 8 割が水分である。しかし、 体が小さいため全体の予備能は少なく、投与される輸液により水分量、電解質、血糖 值は容易に変化する。1957 年に Holliday \& Segar が提唱した小巟維持輸液の計算式 がこれまでの常識とされてきた。1990 年代終盤においても、小児の輸液と言えば「4-21rule」、術中術後輸液は低張液の投与が主流であった。しかし 1992 年以降、低張液 による低ナトリウム血症の報告が相継ぎ、2000 年に入ると低張液輸液は疑問視され始め た。また、抗利尿ホルモン分泌充進も低ナトリウム血症の一因であることが明らかとなった。 それでもなお、6 割の麻酔科医（英国）は低張液を周術期輸液として使用していたこと が Way らにより報告されており、2006 年当時において低張液神話は健在であった。福 岡市立こども病院では現在、1\%ブドウ糖加䣷酸リンゲル液を標準輸液としている。全身 状態良好な小児の中等度侵襲手術では、1-2\%ブドウ糖加輸液を用いれば低血糖・高 血糖を来すリスクは少ない。しかし、未熟児や新生児の侵襲の大きな手術ではより多く のエネルギーを必要とするため、必要十分量の糖が必要となる（5\% 糖液など）。また、 出血が予想される手術（心臟外科、脊椎手術）では、ヒドロキシエチルデンプン注射 液を容量負荷のために用いている。 
PD06-4 高炭水化物含有補水液を用いた術前経口補水の有用性について

吉村速

福岡県済生会福岡総合病院 麻酔科

数年前まで、定例手術の際には麻酔導入時の誤慧少スク軽減のため、画一的に長時間 の絶飲食を患者に指示してきた。しかし、近年では術前の clear fluid 摂取は ASA(American Society of Anesthesiologists) ガイドラインなどにより手術 2 時間前まで可 とする考えが浸透してきている。さらに、術前の高炭水化物付加飲料の摂取は ERAS(Enhanced recovery after surgery) プロトコルの観点からも推奨されている。今回、 当院で高炭水化物含有補水液（アルジネードウォーター TM; AW）を用いた術前経 口補水を導入するにあたり、補水が手術室入室時の胃液・血糖值・血中電解質に及 ぼす影響について調査するとともに、患者に導入前後での満足度調査を行い、その有 用性を検証した。AW は炭水化物を含有しアミノ酸や微量元素を含むなど高張性かつ 高カロリーであるため、胃内容物の排泄遅延、電解質異常や高血糖が䀣念されたが、 調査の結果、入室時の胃液・血糖值・血中電解質には特に影響を及ぼさず、胃液量 はかえって減少傾向であった。また、調査期間を通して麻酔導入時の誤嬩は発生しな かった。AW 導入前後で行った患者アンケートでも術前経口補水の満足度は良好であっ た。ERAS の観点も含めて高炭水化物含有補水液の術前投与は有効かつ安全であるこ とが確認された。運用面も含めて文献的考察を加え、高炭水化物含有補水液を用いた 術前経口補水の有用性について検討したい。

\section{PD07-1大腸癌単孔式腹腔鏡下手術の工夫}

日比健志, 齋藤充生, 木川岳, 根本洋, 真田裕

昭和大学藤が丘病院 消化器外科

【目的】我々は単孔式腹腔鏡下手術の普及を目指し、安全かつ可能な限り平易に行う ために、臍の皮切とトロッカーの挿入に工夫を加えている。【方法】単孔式の欠点は鉗 子間距離が短いために鉗子の取り回しが悪いことである。そのため単孔であっても、可 能な限りトロッカーの挿入孔は離れるようにしている。手術においては最終的に腫瘍を 臍の皮切から取り出す事から、皮切は腫瘍の短径より $1 \mathrm{~cm}$ 小さく行う事で、腫瘍を取り

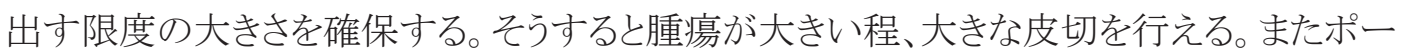
卜扱入デバイスを用いると創が円形に広がってしまうため鉗子間の距離が短くなる。卜ロッ カーを腹壁に直に挿入することで、創を直線的に広げ、十分なトロッカー間の距離を稼 いでいる。ドレーン孔は手術最初から鉗子孔として利用している。【成績】現在までに 119 例（腹会陰式直腸切断術 1 例、低位前方切除術 9 例、高位前方切除術 30 例、 S 状結腸切除術 22 例、左結腸切除術 13 例、横行結腸切除術 4 例、右結腸切除術 18 例、回盲部切除術 22 例）に単孔式手術を施行している。技術認定医の元であれば、 執刀は通常の鏡視下手術を行う技量があれば可能であると考えている。手術時間は 90-460 分、出血量は 0-430 $\mathrm{ml}$ と幅があるが、短期術後合併症は今まで認められず、 いずれの患者も 2 週間以内に退院可能となっている。 


\section{PD07-2 80 歳以上の超高齢者における結腸・直腸癌に対する腹腔鏡下手術の 検討}

関野誠史郎，木村真樹，村瀬勝俊，関野考史

岐皁大学医学部高度先進外科

【目的】高齢者を対象とした大腸腹腔鏡下手術において 80 歳以上と 70 歳代の手術成 績を比較検討し、その安全性、短期成績について検討寸る。【方法】当院で行われた 2006 年 1 月から 2011 年 7 月までに施行された高齢者（70 歳以上）にたい寸る結腸・ 直腸癌腹腔鏡下手術 34 例を対象と寸る。そのうち 80 歳以上が 9 例 70 歳代は 25 例 であり、手術時間・出血量 - 経口摂取開始日 - 術後在院期間 - 合併症について比較 検討した。【結果】比較検討した項目では有意差のでるものはなかったが、手術時間・ 経口摂取開始に関しては 80 歳代で短い傾向があり（手術時間：294 vs $271 \mathrm{~min}$, $\mathrm{P}=0.41$ )、(経口摂取開始 : 3.42 vs 2.22 日, $\mathrm{P}=0.37$ ) 出血量はほぼ同等で（140 vs $151 \mathrm{ml}, \mathrm{P}=0.92)$ 術後在院日数ではやや 70 歳代の方が短い傾向があった。（15.8 vs 19.1 日 $\mathrm{P}=0.55)$ 開腹移行は 70 代で 3 例、 80 歳以上では 0 例、合併症の発生率で は 70 歳代に少ない傾向があったが、(28 vs 44\% P=0.936) で差は認められなかった。 70 歳代での合併症内容は ( 縫合不全 2 例、イレウス 2 例、SSI1 例、下血 2 例) で 80 歳以上は（縫合不全 0 例、イレウス 2 例、SSI 1 例 下血 1 例)であった。【結語】 80 歳以上でも治療成績はそれ以下の高齢者と同等の短期手術成績が得られており、 腹腔鏡下手術を遂行していくことが可能であると思われた。

\section{PD07-3 術前化学放射線療法併用腹腔鏡下直腸切除術後の肛門機能について}

森本慎也, 島田光生, 栗田信浩, 岩田貴, 佐藤宏彦, 吉川幸造, 宮谷知彦, 高須千絵，柏原秀也

徳島大学 消化器移植外科

［はじめに］大腸癌に対する腹腔鏡下手術は、結腸癌では進行癌にも適応されている が、直腸癌、特に下部直腸癌に対しては今日でも早期癌に限定されている。我々は 2004 年から進行直腸癌に対しても腹腔鏡下手術を導入し、さらに進行下部直腸癌に対 しては術前化学放射線療法（CRT）を行った後に腹腔鏡下手術を行っている。CRT 後腹腔鏡下直腸切除術後の長期肛門機能について検討したので報告する。[対象・ 方法］対象は CRT 後腹腔鏡下直腸切除術を施行した 30 例で、肛門機能に関しては Covering ストーマ閉鎖後 6 ケ月以上経過した 19 例で検討した。検討項目はストーマ閉 鎖後 6 ケ月、 1 年、 2 年、 3 年後の Wexner score、排便回数。術前 CRT は経口抗癌 剂 S-1 または UFT と体外放射線 4 門照射 40Gy で行った。［肚門機能］Wexner score は 6 ケ月で $8.1 、 1$ 年で $6.0 、 2$ 年で $4.2 、 3$ 年で 2.4 であった。排便回数は 6 ケ 月で 9.2 回、 1 年で 6.4 回、 2 年で 4.6 回、 3 年で 3.8 回であった。再建別では DST 法の Wexner score/ 排便回数は 6 ケ月で 7.8/9.1、 1 年で 5.6/6.6、2 年で 3.0/5.5、3 年で 2.3/5.0 で、ISR（経肛門吻合法）の Wexner score/ 排便回数は 6 ケ月で 8.6/9.3、 1 年で 6.6/6.1、2 年で 2.5/3.6、3 年で 2.5/2.0 であり、有意差を認めなかった。[まと め] ISR を含めた CRT 後腹腔鏡下直腸切除術は、手技の定型化と工夫により安全に 施行可能で、肚門機能も経時的に改善されることより、進行下部直腸癌に対する腹腔 鏡下手術の適応拡大を可能とする。 


\section{PD07-4＼cjkstart安心ブックレットを用いた大腸がん患者ケア}

保田尚邦, 諸原浩二

伊勢崎市民病院 外科

【はじめに】大腸がん患者とのコミュニケーションやインフォームドコンセントそして患者教 育の充実のためのツール（安心ブックレット）を作成・導入してきた。初診から5年生 存もしくは死亡の転帰までまた患者の状況に広く対応できるように安心ブックレットを 5 冊 に増刊した。現在までの作成経過と臨床経験を報告する。【対象と方法】 2009 年 7 月 からの外科治療を要する大腸がん患者に安心ブックレットを配布した。安心ブックレット】 手術入院・安心ブックレットは、入院する患者への小冊子で、術後 6 日で退院するクリ ニカルパスを含む。術後経過・安心ブックレットは、退院時から使用する冊子で、術後 の地域連携 5 年分の受診記録がある。ストーマをもつ患者には、ストーマ生活・安心ブッ クレットで教育指導を行う。外来化学療法・安心ブックレットは院内連携に使用する。 緩和ケア・安心ブックレットは、在宅を目指したギアチェンジに用い、EBM ある生命予 後予測（KPS、PPI など）のできる表を利用した日記からなる。【結果】2011 年現在、 手術入院・安心ブックレッ卜は年間約 70 例が新規に、そして地域連携はすでに 100 例 に行われケアされている。外来化学療法と、ストーマに関しては院内連携をそれぞれ約 20 例に行っている。ギアチェンジの推進により死亡 15 例の 7 割が自宅で永眠できた。結 語】安心できる大腸癌治療の実践には患者ケアの充実が不可欠と考えられた。

\section{PD07-5 消化管機械的前処置は術後小腸運動麻痺を遷延させる}

山田岳史, 菅隼人, 松本智司, 小泉岐博, 進士誠一, 佐々木順平, 内田英二 日本医科大学 外科

【背景】ERAS が注目されており、術前機械的前処置 (Mechanical Bowel Preparation: MBP）を行わない方が、早期回復につながるとされている。しかし ERAS がよいとされ る指標は入院期間であり客観的な評価とは言いがたい。我々はこれまで放射線不透過 マーカーSITZ MARKS を用いて術後消化管運動麻痺を評価してきたが MBP は大腸よ りも小腸運動に影響を与える可能性が高いと考えている。今回は小腸内のマーカー残 存数に注目して MBP が術後腸管運動に与える影響の評価を行ったので報告する。【目 的】MBP の有無によりマーカーの排泄速度が変わるか否かを検討する。【方法】対象 は結腸癌 173 例。術当日朝に SITZ MARKS を内服し、術後 1、3、5 日目に腹部X 線を撮影し小腸内マーカー残存数を数え、Mann-Whitney U-test にて検討を行った。 【結果】(1) 左側結腸は右側結腸よりも有意に麻痺が遷延していたため、それぞれを分 けて検討した。(2) 右側、左側結腸ともに術後 1 日目から 5 日目までいずれも MBPを 行わない群で有意に小腸内残存マーカー数が少なかった。【考察】右側と左側では術 後消化管運動麻痺の程度が異なる可能性があることが示唆された。機械的前処置は術 後の小腸運動に影響を与え術後腸管運動麻痺を遷延させることが示唆された。現在は 前処置のない症例にて、鏡視下手術の有用性や輸液量の影響を検討している。 


\section{PD07-6 大腸癌における組織型別の病理学的因子に基づいた治療方針}

松山歩, 木村和恵, 吉永敬士, 武石一樹, 本間健一, 竹中朋佑, 辻田英司, 山下洋市, 筒井信一, 松田裕之, 石田照佳

広島赤十字・原爆病院 外科

【目的】大腸癌における中分化腺癌の臨床病理学的因子を解析寸ることにより，その特 徵を捉える.【対象】当院外科で $2000 \sim 05$ 年に切除を施行した 457 例.【結果】平 均年齢 67.5(33-93) 歳, 男性 : 女性 $=262: 195$ 例, 結腸 : 直腸 $=325: 132$ 例, 高分化: 中分化 : 低分化 $=331: 113: 13$ 例であった. 中分化腺癌の年次変化では増加傾向にあっ た. 全例における臨床病理学的因子解析では, 中分化腺癌は高分化腺癌に比して, 深達度が深く $(\mathrm{p}=.0002)$, リンパ節転移の頻度が高く $(\mathrm{p}<.0001)$, 脈管侵襲が高度であっ た (ly; p <.0001, v; p=.008). 深達度別解析では, $\mathrm{sm}$ (高分化: 中分化 $=31: 9$ 例 ) お よび $\mathrm{mp}$ (高分化: 中分化 $=46: 17$ 例) で $\mathrm{v}$ 因子 (それぞれ $\mathrm{p}=.008$ ) が， ss/a1( 高分化: 中分化 $=166: 86$ 例 ) と se,si/a2, ai (高分化 : 中分化 $=23: 27$ 例 ）においてはリンパ節転移 $(\mathrm{p}=.05,=.04)$ と $\mathrm{v}$ 因子 $(\mathrm{p}=.0005, .04)$ が，中分化腺癌で高度であった。腫瘍長径 $30 \mathrm{~mm}$ 以下の症例 (高分化: 中分化 $=99: 39$ 例) においては, 深達度 $(\mathrm{p}=.02)$, リンパ 節転移 $(\mathrm{p}=.01)$, 脈管侵襲 $(\mathrm{ly} ; \mathrm{p}=03, \mathrm{v} ; \mathrm{p}=.02)$ ともに中分化腺癌で高度であった.【結 語】中分化腺癌に対しては, 小病変, sm 癌であったとしても, 十分な郭清が必要であ る.

\section{PD07-7 当科における大腸癌治療成績}

太田尚宏, 三輪武史, 申寿東, 村杉桂子, 吉田周平, 出村嘉隆, 加藤洋介, 尾山佳永子，奥田俊之，原拓央

厚生連高岡病院外科

【背景】大腸癌の治療成績は新規抗癌剤の出現、新しいレジュメの開発により飛躍的 に進歩している。その過程は、エビデンスの蓄積を根拠に導入されている。しかしな がら欧米との手術成績の違いなどから、導入による治療成績の向上が、疑問視される 部分も否めない。施設ごとの治療成績を把握し、レジュメの導入の助けとすることが肝 要と考え、当科の治療成績を提示する。【対象】 2005 年 1 月から 2006 年 12 月まで、 手術が施行された 193 症例。男性 108 例、女性 85 例。年齢は 32 歳から 96 歳。中 央值 70 歳。【結果】 5 年生存率は $66.8 \%$ 。また、病期別では II 期 $85.0 \%$ 、IIIa 期 $75.0 \%$ 、IIIb 期 $54.5 \%$ 、IV 期 8.3\% であった。II 期における補助化学療法の有無で比 較すると、補助化学療法なしで $76 \%$ 、補助化学療法ありで $93.9 \%$ あった。また IIIa 期では補助化学療法なしで $83.3 \%$ 、ありで $72.7 \%$ 。一方 IIIb 期では補助化学療法な しで $33.3 \%$ 、ありで $62.5 \%$ であった。【結語】II 期では補助化学慮法を行うことで、予 後の改善が認められたが IIIa 期では生存率の改善は認められなかった。補助化学療法 が真に有効な症例は限られており、補助化学療法を検討寸る際に、十分な症例選択が 必要と考えられた。 


\section{PD08-1 当科におけるパニツムマブ使用経験}

湯川寛夫 , 利野靖 , 佐藤勉, 稲垣大輔, 山田六平 , 大島貴 , 藤川寛人, 山奥公一朗, 山本直人, 玉川洋, 益田宗孝

横浜市立大学 外科治療学

2010 年 11 月以降、当科でパニツムマブを使用した進行再発大腸癌症例について検討 寸る。対象は 8 例（男性 4 例女性 4 例）で全例 K-ras 野生型、投与開始年齢は平 均 68.5 歳 ( $59 \sim 85$ 歳)。対象臟器は肝 5 例, リンパ節 4 例, 腹膜播種 2 例, 原発 巣 1 例（重複あり）。併用レジメンは FOLFIRI 5 例, CPT-11 2 例, 単剂 1 例であった。 first line での使用が 2 例、second line 3 例で 3 rd 以下は 3 例で、使用サイクル数は 1 〜 16 回（中央值 7.5 回）であった。抗腫瘍効果は PR 4 例, MR 1 例, PD 2 例で病 勢コントロール率は $62.5 \%$ であった。有害事象は $62.5 \%$ に好中球減少を主と寸る血液毒 性が出現し、うち grade3 以上は 50\% であったが、休薬や G-CSF 投与によりコントロー ル可能であった。非血液毒性はざ瘡様皮疹 (87.5\%), 倦㤐感 (50\%), 爪周囲炎/手足 症候群 / 未梢神経障害 (いずれも $37.5 \%$ ) などであった。本薬剤に特有のざ瘡様皮疹, 爪周囲炎については投与初期加皮膚科医と連携をとり積極的に予防，重症化防止を 図っている。パニツムマブは併用薬剤との組み合わせで、様々な line で使用できる薬 剂である。より早い段階での使用により更に効果が期待できると推察され、また特有の 有害事象のコントロールが使用継続に重要である。

\section{PD08-2 大腸癌肝転移に対する Bevacizumab 用いた術前化学療法の治療成績}

播本憲史, 梶山潔, 平山佳愛, 九十九悠太, 能美昌子, 中八子智徳, 由茅隆文，吉田倫太郎，植田直之，西田康二郎，永田茂行，古賀聡， 甲斐正徳，長家尚

飯塚病院 外科

【はじめに】Bevacizumab(BV) を用いた化学療法は進行再発大腸癌の生存期間の延長 に寄与しており、大腸癌肝転移に対する BV を用いた術前化学療法が有用であるか検 討した。【対象】 2003 年 1 月から 2010 年 12 月までに大腸癌肝転移の診断で肝切除 を行った 78 例のうち術前化学療法を行ったのは 27 例。その内新規抗癌剤 (FOLFOX,FOLFIRI,XELOX)を行ったものが 20 例であった。さらにBVを用いたのをA 群 $(\mathrm{n}=10) 19$ 結節、用いなかったのを B 群 $(\mathrm{n}=10) 17$ 結節とし臨床病理学的因子を比較 検討した。【結果】平均観察期間 A 群 283 日、B 群 876 日。A 群 5.9 サイクル (3-10)、 B 群 6.2 サイクル (2-12)。両群間の腫瘍因子、宿主因子に差を認めなかった。病理組 織診断にて完全壊死は $\mathrm{A}$ 群 3 例 7 結節 $(36.8 \%) 、 \mathrm{~B}$ 群 0 結節。化学療法前後の腫瘍マ一 カーは A 群 (CEA: $41.7 \pm 54.7 \rightarrow 14.6 \pm 21.5) 、 B$ 群 (CEA: 50.5 $\pm 117.6 \rightarrow 45.4 \pm 84.2$,)、 腫瘍径の推移は A 群 $3.7 \pm 2.8 \rightarrow 2.6 \pm 1.9 \mathrm{~cm} 、 \mathrm{~B}$ 群 $1.5 \pm 1.2 \rightarrow 2.0 \pm 1.1 \mathrm{~cm}$ であった。 術後合併症は A 群 0 例、B 群 2 例 (イレウス、深部 SSI) であった。CR を得た 3 例は いずれも無再発生存中である (126-565 日)。【結論】術前化学療法として BV を併用 することで、組織学的 CR を得ることが可能となり、短期治療成績が向上する。長期予 後については今後の観察が必要である。 


\section{PD08-3 当院における first line での panitumumab 投与症例の検討}

村越雄介，久田将之，石崎哲央，河北英明，和田建彦，土田明彦，青木達哉

東京医科大学 外科学第 3 講座

切除不能な大腸癌の化学療法において, オキサリプラチンやイリノテカンに加え, 分子 標的薬が加わったことで奏効率や生存期間の成績は大きく向上した .また近年 , 切除不 能であった肝転移症例が，これらの治療により切除可能となる報告が増加している。今 回, 完全ヒ下型抗 EGFR モノクローナル抗体である分子標的薬 panitumumab (ベクテイビ クス ${ }^{\circledR}$ ) 投与症例を 20 例経験したので治療成績を報告する。本剂は，比 EGFR（上皮 細胞増殖因子受容体）に対するヒ卜型モノクローナル抗体であり, EGFR を介したシグナ ル伝達は, 腫瘍細胞の増殖, 遊走, 間質浸潤, アポトーシス抵抗性や腫瘍組織におけ る血管新生に関与すると考えられている。症例は 2010 年 8 月から 2011 年 11 月までの 間に投与された KRAS 遺伝子 wild type の治瘉切除不能な結腸・直腸癌患者に対して panitumumab 投与を行った 20 例 。これらの症例について, 1 次治療群および 2,3 次治 療群の 2 群間での治療成績を検討した。今回，CR 症例はなかったが，1 次治療での $\mathrm{PR}+\mathrm{SD}$ rate は比較的良好な成績であった。今後, 更なる症例を経験し検討する必要 はあるが, panitumumabの first line での投与は有用であると考えられた。

\section{PD08-4 進行 · 再発大腸癌に対する抗 EGFR 抗体薬の治療成績}

宮本裕士, 坂本快郎, 井田智, 石本崇)糺, 長井洋平, 岩槻政晃, 馬場祥史, 岩上志朗, 渡邊雅之, 馬場秀夫

熊本大学大学院 消化器外科学

【目的】抗 EGFR 抗体薬は K-ras 遺伝子に変異がない大腸癌において有用性が示さ れており、1 次治療から 3 次治療まで標準治療として推奖されている。今回、当院にお ける進行再発大腸癌に対する抗 EGFR 抗体薬の使用現状を調查し、治療成績につい て検討した。【対象】 2009 年 01 月から 2011 年 12 月までに当院で抗 EGFR 抗体薬を 使用した KRAS 野生型症例を対象とした。【結果】Cmab の導入 line は 1 次:6 例、2 次： 2 例、3 次以降 : 20 例であった。Pmab の導入 line は 1 次 : 9 例、2 次 : 5 例、3 次 以降：3 例であった。Cmabの奏功率はそれぞれ 1 次 : $50 \% 、 2$ 次 : $50 \%$ であり、3 次 治療の病勢制御率は 58\%であった。Pmab の奏功率は 1 次 : 50\%、2 次 : 40\%であり、 3 次治療の病勢制御率は 66\%であった。また、いわゆる conversion therapy を行った 症例が Cmab で 4 例、Pmab で 1 例存在した。有害事象に関しては Grade3 の皮膚毒 性は Cmab が 14\%、Pmab が 12\%であり、Grade2 以上の爪囲炎は Cmab、Pmab ともに 18\%であった。【結論】使用症例数は未だ少ないが、治療成績としては良好な結果であっ た。皮膚毒性、爪囲炎のコントロールが重要であり、予防的な支持療法を心掛ける必 要がある。 


\section{用な薬剤は?—}

高橋孝夫, 野中健一, 安福至, 棚橋利行, 斉藤史朗, 今井寿, 佐々木義之,

田中善宏, 松橋延壽, 山口和也, 長田真二, 吉田和弘

岐阜大学

切除不能・進行再発大腸癌に対寸る化学療法は近年分子標的薬の登場により進歩し た。1.2005 年 4 月から切除不能大腸癌に対し、一次治療しして原則 FOLFOX を施行、 2.2007 年 9 月から FOLFOXに Bevacizumab (BV)を使用、3.2010 年 7 月から KRAS 野生型症例には FOLFOX に Cetuximab(Cmab) を使用してきた。化学療法が奏効し根 治手術を行う Adjuvant Surgeryに積極的に取り組んできた。【目的】Adjuvant Surgery の観点からどの分子標的薬が有用となるか検討した。【方法】2005 年 4 月より 2011 年 6 月まで切除不能大腸癌 218 例に化学療法を行い、30 例 (13.8\%) に Adjuvant Surgery 可能となった。一次治療レジメンはそれぞれ FOLFOX: 117 例 ,FOLFOX+BV: 42 例, FOLFOX+Cmab: 6 例, その他 :53 例であった。切除率、根治術までの治療回数をレジ メン毎に検討する。【結果】切除率はそれぞれFOLFOX:18/117 例 (15.4\%), FOLFOX+BV:4/42 例 (9.5\%), FOLFOX+Cmab:2/6 例 (33.3\%) であった。根治術までの 平均治療回数はそれぞれFOLFOX:9.9 (3-23), FOLFOX+BV:11.3 (6-26), FOLFOX+Cmab: 5 （5）であった。mFOLFOX6+Cmab 療法を施行した 6 例における奏 効率は 66.7\%(CR: 1 例、PR:3 例 ) であった。奏効例の 8 週後早期縮小率間は 53.8\% (34-80\%), 全経過最大縮小率は 81.5\% (67-100\%) であった。【考察】早期に縮小し、縮 小率が高いことより adjuvant surgery に持ち込むには FOLFOX+EGFR 抗体 Cmab が有 用であると考え、症例の更なる蓄積を行う。

\section{PD09-1 高齢手術患者における術後せん妄の発症予測 一高齢者手術成績向上 のためにー}

北川雄一 ${ }^{1}$, 深田伸二 ${ }^{1}$, 川端康次 ${ }^{1}$, 藤城健 ${ }^{1}$, 原田敦 ${ }^{2}$, 服部英幸 ${ }^{3}$

${ }^{1}$ 国立長寿医療研究センター 外科, ${ }^{2}$ 国立長寿医療研究センター 整形外科, ${ }^{3}$ 国 立長寿医療研究センター 精神科

【目的】高齢者手術の際、術後せん妄の発症は、安静保持困難、吸痰などの施行困難、 ドレーンやカテーテル類の自己抜去、誤嬹性肺炎の発症など、様々な合併症の原因、 誘因となる。当センターで全身麻酔下手術を施行した患者において、術後せん妄予測 の可能性について検討した。【方法】国立長寿医療センター病院の外科・整形外科で、 全身麻酔下で予定手術が施行された 80 歳以上の患者のうち、必要なデータのそろっ た 88 例を対象とした。患者の性、年齢、MMSE（Mini-Mental State Examination）、 術前 JNCS (Japanese version of the NEECHAM Confusion Scale)、E-PASS (Estimation of Physiologic Ability and Surgical Stress)、SF-8 Health Survey、EQ-5D (EuroQoL5D)、術前合併症、失禁既往、興奮・多動既往、血液検査デー夕、担当科、原疾患、 術式、輸血量、手術時間、出血量、治療を要寸る術中血圧変動、術後合併症と、術 後 0 から 10 日目の JNCS を調查した。【成績】術後せん妄は 65 例（73.9\%）に見られ た。せん妄を発症した群はより高齢で、術前 MMSE が低い認知症の症例が多く、術前 の JNCS が低かった。また興奮・多動既往を有寸る患者が多かった。【結論】術前か らの認知症や興奮・多動の既往あるいは、入院時点ですでにせん妄状態にある患者 では、術後せん妄の発症および悪化が生じる可能性がある。こうした患者を対象に、 術後管理の方法の検討や、薬物による予防を考慮すべきである。 


\section{PD09-2 高齢者裖瘡手術成績向上におけるエ夫一他施設重症患者の受け入れ 手術の経験から一}

小坂正明, 坂本忠秀, 山城由莉

福岡山王病院 形成外科

【緒言】高齢者の裖瘡は保存的治療が原則であるが深達性裖瘡は難治で手術が必要 な場合もある。欠損を適切に閉鎖できれば全身状態も安定するが、在宅医療などでは 手術を躊躇して漫然と保存的治療が続けられる例もあり啓発が必要である。われわれは 他施設の難治症例を受け入れて手術を行ってきた経験を踏まえて高齢者裖瘡手術にお ける治療成績向上の工夫を述べる。【方法】他施設から受け入れ治療の手順は、 Step-1：地域連携室を通して依頼を受ける。Step-2 : 術前状態について情報交換し入 院日を決定。Step -3 : 入院、術前検査。関連科・麻酔医に併診。Step $-4:$ 手術 - 術 後管理。Step-5 : リハビリ、ケア計画を作成し紹介元に帰す。【結果】1998 年より仙骨 部裖瘡 124 例に穿通動脈皮弁術を実施した。症例は院内発生 19 例（15.3\%)、出張 手術 79 例（63.7\%)、他院受け入れ手術 26 例（21\%）でその一次治癒率は $96.3 \%$ であった。【考察】高齢者の難治性裖瘡手術で重視寸るのは以下の 3 点である。Step1 : 手術適応は、難治性の深達性裖瘡、安定した全身状態、主な治療が裖瘡、など である。Step-2：貧血や低蛋白血症の改善のほか巨大裖瘡では陰圧閉鎖療法などで 創を縮小させる。Step-4 : 術後は病棟スタッフとの連携が不可欠である。執刀医が体の 支え方、介助時の手の位置などを実演しスタッフ全員に共通の意識を持たせる。【結語】 治癒率向上には周到な術後再発予防策と厳重な follow up が不可欠である。

\section{PD09-3 80 歳以上高齢者肝細胞癌に対する肝切除の妥当性と安全性について}

前原伸一郎, 池田泰治, 知念順樹, 岩永彩子, 古城都, 杉山雅彦, 大垣吉平, 南一仁, 森田勝, 坂口善久, 藤也寸志, 岡村健

国立病院機構 九州がんセンター

くはじめに＞肝癌に対する治療は集学的治療により飛躍的な進歩を遂げた。その一 方、高齢化が進んでいる外科的治療の対象患者においては心肺機能の低下や併存疾 患等の問題にて、一般的に高侵襲の治療は避けられる傾向にある。当院では肝癌ガイ ドラインに沿って 80 歳以上の超高齢者の肝細胞癌に対しても積極的に外科治療を行っ ており、今回はその手術の妥当性について検討した。＜対象＞2006 年 1 月から 2011 年 12 月までに施行した 80 歳以上の肝細胞癌肝切除症例（9症例 10 手術）について その特徵、短期成績および臨床病理学的検討を行った。＜結果＞平均年齢は81.2 歳、 男性 8 人、女性 2 人。肝機能は全例が肝障害度 A、Child-Pugh A であり、平均腫瘍 径 $4.0 \mathrm{~cm}$ であった。術式は部分切除 4 例、亜区域切除 4 例、中央 2 区域切除 1 例、 右葉切除 1 例で、根治切除が可能であった。ウイルス感染は非 B 非 C 型 4 例、C 型 肝炎 4 例、B 型肝炎 2 例であった。再発症例は 2 例、他臟器癌の合併（同時性、異 時性を含む）は 4 例であった。術後合併症は術後せん妄が 2 例、胸水・腹水 3 例、 胆汁漏 1 例であったが保存的に治療可能であった。術死、在院死は認められず平均 在院日数は 23.8 日であった。〈まとめ>高齢者肝細胞癌に対する外科的治療は、適 切な術前評価により肝癌ガイドラインに沿って安全に施行できる。 


\section{PD09-4 80 歳以上超高齢者の胃癌手術におけるリハビリの役割}

井口友宏，河野麻優子，根東順子，野添忠浩，前田貴司，江崎卓弘

独立行政法人国立病院機構 福岡東医療センター

我が国では、高齢化が急速に進展しており、高齢者に対して外科的手術を施行する機 会が増えている。一方で、術後の早期離床は合併症の予防などに大きく寄与している。 しかし、高齢者の ADL は良いとは言えず、早期離床に与える影響は大きい。当院では、 術後に理学療法士による積極的なリハビリを行っており、その役割について検討する。 平成 21 年 1 月〜平成 23 年 12 月に胃癌に対し、切除を行った 88 例のうち、 80 歳以 上の超高齢者 21 例を対象とする。年齢は 83.1 2.4 歳であり、術前の Performance status は 0 が 13 例、 1 が 5 例、 2 が 2 例、 3 が 1 例であった。基礎疾患は高血圧、 糖尿病、虚血性心疾患、不整脈、肺結核など 17 例に認めた。術式は幽門側胃切除 術が 15 例、胃全摘術が 4 例、残胃全摘術 2 例であった。全例、術後 1 日目よりリ八 ビリを開始した。座位、立位、歩行までに至る平均日数はそれぞれ、1.05 日、1.9 日、 2.9 日であった。合併症は 8 例に認めた。内訳は、吻合部狭窄 1 例、縫合不全 2 例、 胆汁漏 2 例、肺炎 1 例、不整脈 1 例、敗血症性ショック 1 例であった。術後在院日 数は 38.6 22.0 日であり、退院時に Performance status が低下した症例は 2 例のみで あった。術後早期より積極的にリ八ビリを導入することにより、早期離床が可能であり、 その役割は大きいと考えられるが、もともとの ADL や基礎疾患に起因する合併症、そ れに伴う在院日数の延長を認め、課題は多いと考えられた。

\section{PD09-5 高齢者食道癌手術成績向上におけるエ夫}

成宮孝祐, 大田正穂，佐藤拓也，白井雄史，山本伸，井手博子，大杉治司， 山本雅一

東京女子医大 消化器外科

（はじめに）高齢者社会の到来により併存疾患を高率に有する高龃者食道癌患者の割 合が増加している。当科受診された最近 6 年間における高齢者食道癌患者現状につき 検討を加えたので報告する。（対象） 2006 年より 2011 年まで当科で加療された 75 歳 以上の食道癌患者 73 例 1) 術前の併存疾患 2 治療方法 3) 術式 4) 手術合併症（結 果）1）術前併存疾患は呼吸機能異常 (55\%), 心疾患 (33\%), 脳疾患 (13\%) の順に認めら れ、2 個以上の併存疾患を有寸る症例は 25\% に認められた。2）手術治療 33 例、化 学放射線治療 40 例 (重複癌 17 例に認められ、術前併存疾患は 37 例)(3) 術式は右 開胸 / 左開胸 / 開腹手術 16/10/7 と右開胸以外が $52 \%$ と多く選択され、再建経路は 胸腔内吻合が $64 \% 、 3$ 領域郭清された症例は 1 例のみであった。(4) 手術後の合併症 は肺炎, 腸閉塞、せん妄がやや多いが食道癌全手術症例と比較し在院日数 $42.3 \pm 3.4$ 日（ $\mathrm{P}=0.001 ） の$ 延長を認めたが $\mathrm{SIRS}$ 日数は $1.7 \pm 2.9$ 日（P=0.022）と逆に短縮 されていた。(結論) 高齢者食道癌患者は重複癌や併存疾患を多く有するため、75 歳 未満の食道癌患者と同等の手術成績と合併症発生率を保つためには、手術患者の適 応 (進行度、占居部位)を絞り、郭清を手控えた縮小手術などの工夫が必要であると 思われる。 


\section{PD09-6 80 歳以上の高齢者に対する膵頭十二指腸切除術の検討}

梶山潔，播本憲史，永田茂行，平山佳愛，九十九悠太，能美昌子， 吉丸耕一郎，中ノ子智徳，由茅隆文，吉田倫太郎，植田直之，西田康二郎， 古賀聡，甲斐正徳，長家尚

飯塚病院 外科

【背景・目的】膵頭十二指腸切除術 (PD) は高度の侵襲を伴う手術であるが、高齢化 社会に伴いPD を必要とする症例も増加している。特に 80 歳以上の高齢者では、術後 いかに早期に退院させるかが、その後の QOL にも大きく影響すると思われる。今回、 当院における 80 歳以上の PD 症例を解析し、早期退院に必要な因子を検討した。【対 象・方法】 2002 年 1 月より 2011 年 12 月までに当科で施行された PD159 例中 80 歳 以上の症例 12 例 $(7.5 \%$ ) を対象とした。手術時間、出血量、膵液瘻、執刀医の経験、 術後在院日数等の臨床的事項を解析した。【結果】平均年齢 83.0 歳 $(80 \sim 89$ 歳)。 男性 : 女性 $=2: 10$ 。疾患は、十二指腸乳頭部癌 3 例、胆管癌 5 例、膵頭部癌 4 例 であった。平均手術時間 486.7 分、平均出血量 $1094.5 \mathrm{ml}$ 。術後膵液瘻は、ISGPF 分 類による膵液瘻なし 2 例、Grade A 5 例、Grade B 5 例であつた。術後在院日数は平 均 39.1 日（14〜 76 日）、在院死亡はなかった。早期退院に影響すると思われる因子は、 100 例以上の PD 経験を持つ術者の関与、膵液瘻の有無、膵管ロストステントの使用で あった。【結語】高齢者のPDにおいては、PD 経験豊富な外科医の関与が術後膵液 瘻の合併を減少させる可能性がある。また、膵管ロストステントなど早期に退院できる工 夫も必要である。

\section{PD10-1 75 歳以上の高齢者に対する膵頭十二指腸切除術は安全である}

木村真樹, 關野考史, 關野誠史郎, 村瀬勝俊, 竹村博文

岐阜大学医学部高度先進外科

はじめに：当科では高侵襲である膵頭十二指腸切除術も全身状態を検討し耐術可能と 考えられれば高齢者にも施行してきた。目的 : 膵頭十二指腸切除を施行した 75 歳以 下の症例と 75 歳以上の症例の手術成績を比較し安全性を検討する。対象 : 術後 synbiotics を併用し早期経腸栄養を用いた術後管理を開始した 2007 年 3 月以後に膵頭十 二指腸切除術を施行した 28 例で、HPD の 1 例を除いた 27 例の 75 歳以下の患者の 18 例を Y 群、76 歳以上の患者の 9 例を $\mathrm{O}$ 群とした。方法 : Y 群と $\mathrm{O}$ 群の出血量と手 術時間、術後 3 日目、7 日目、14 日目、21 日目のアルブミン值、リンパ球数、体温 と合併症の有無、排ガス、排便を認めた日を比較する。結果 : Y 群が $60 \pm 9$ 歳、 $\mathrm{O}$ 群

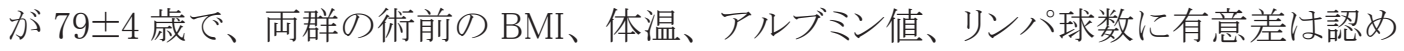
なかった。出血量と手術時間に有意差は認めなかった。Y群のアルブミン值は 7 日目、 14 日目、21 日目に有意に O 群より高值であった（p<0.05）。21 日目の CRP 值と 7 日目の体温も有意に低值であった $(p<0.05)$ 。排ガスと排便を認めた日に有意差なかっ た。Y 群に 2 例の膵液瘻と 2 例の胃内容排泄遅延、 $\mathrm{O}$ 群に 1 例の胃内容排泄遅延と 1 例の創感染を認めた。結論 : 高齢者はアルブミン值の回復と CRP 值と体温の正常化 が遅れたが、合併症の発症に有意差はなく脺頭十二指腸切除は安全に施行可能であ ると考えられた。 


\section{PD10-2＼cjkstart高齢者における悪性骨軟部腫瘍治療成績向上のための工夫}

五嶋孝博 ${ }^{1}$, 津田祐輔 ${ }^{1}$, 池上政周 ${ }^{1}$, 江夏元揚 ${ }^{1}$ ，山川聖史 ${ }^{1}$ ，穂積高弘 ${ }^{1}$ ， 福田由美子 ${ }^{2}$, 加藤生真 ${ }^{2}$, 元井亭 ${ }^{2}$, 比島恒和 ${ }^{2}$

1 がん・感染症センター都立駒込病院 整形外科・骨軟部腫瘍科, ${ }^{2}$ がん・感染症 センター都立駒込病院 病理科

【緒言】高齢者人口の増加に伴い、転移性骨腫瘍を含む高齢者の悪性骨軟部腫瘍が 増加している。高齢患者での生存率や生存期間、QOLなどの治療成績向上のための 工夫を紹介する。

【治瘉が期待できる腫瘍】局所腫瘍の根治性が最重要である。たとえ高齢者であつても、 四肢の腫瘍には治癒的広範切除を行うようにしている。一方、骨盤や春椎の悪性腫瘍 で広範切除が高齢者にとって侵襲が大きすぎると考えられる場合は、縮小手術を行い、 補助療法として放射線照射や光線力学療法を併用している。重粒子線療法を行うことも ある。高齢者でも、原発性腫瘍では術前に化学療法を行うことが多い。

【治瘉が期待できない腫瘍】長管骨腫瘍に病的骨折を生じると QOL が著しく低下する。 罹患骨の支持性回復を目指して、腫瘍を切除し、金属材料で再建することが多い。一方、 骨盤や脊椎の悪性腫瘍は、少ない手術侵襲で ADL や QOL を改善することが治療の 目標である。骨盤腫瘍は腫瘍を掻爬して、エタノールなどで化学凝固し、骨欠損部に は PMMA 骨セメントを充填し、術後に放射線照射を行うことが多い。一方、春椎腫瘍 による春髄麻痺には、術中放射線照射を併用した除圧及び内固定手術を行うことが多 い。

【リハビリ】高齢者の骨軟部腫瘍では、術後の ADL 低下が重大な問題である。早期リ ハビリが重要であり、手術の翌日には坐位訓練をし、翌々日には車椅子に移乗させて いる。そして、速やかに歩行訓練を行うようにしている。

\section{PD10-3 80 歳以上の肝細胞癌に対する肝切除の治療成績と栄養学的介入効果}

辻田英司，山下洋市，武石一樹，前田貴司，松山歩，筒井信一，松田裕之， 石田照佳

広島赤十字・原爆病院 外科

【対象と検討】クリニカルパスを導入後に栄養学的指標の検討を開始した 2007 年 4 月 から 2011 年 10 月に行った肝癌肝切除症例 294 例を対象。【結果】1)AEN 非内服群と AEN 内服群で、背景因子、手術因子、術後感染性合併症発症率、術後在院日数に 有意差 $(p<0.05)$ なし。2)79 歳以下と比較して 80 歳以上は、HBsAg 陽性 (18 vs. 0\%) が少なく、HCV 陽性 (66 vs.81\%) が多い。術前の Hb(14.8 vs. 13.9g/dL) が低值だが、 背景肝機能 (T.Bil, PT, ICG-R15) には有意差なし。栄養学的指標では、Geriatric Nutritional Risk Index (103.1 vs. 99.6)、preAlb 值 (19.4 vs. 15.7mg/dL) が有意に低值だが、 Alb、T.Chol、BTRに有意差なし。手術時間 (263 vs. 226 分) は短いが、出血量、術 後在院日数に有意差なし。術後 7 日目の Alb、preAlb は同等だが、術後一ヶ月目の Alb(3.9 vs. 3.6g/dL)、preAlb(15.3 vs. 13.3mg/dL) は有意に低值。3)80 歳以上で AEN 内服群は外来受診時よりも術前の preAlb(15.3 vs. $19.8 \mathrm{mg} / \mathrm{dL})$ が有意に改善。さらに非 内服群と比較して、術後一ケ月目の Alb(3.5 vs. 3.8g/dL)、preAlb(11.2 vs. $15.1 \mathrm{mg} / \mathrm{dL})$ が良好だったが、術後感染性合併症発症率、術後在院日数に有意差なし。【まとめ】 AEN 内服で肝癌による肝切除後短期成績の改善はみられなかった。80 歳以上の症例 では術後一ヶ月での栄養学的回復が遷延するが AEN 追加投与は改善の一助となる可 能性がある。 


\section{PD10-4 80 歳以上の超高齢者食道癌に対する手術成績と将来戦略}

大賀丈史，安藤幸滋，佐伯浩司，沖英次，掛地吉弘，辻谷俊一，鴻江俊治， 前原喜彦

九州大学大学院 消化器・総合外科

【背景・目的】食道癌は高齢者に多い一方で、外科治療は過大な侵襲が故に高齢者 に対しては行えないことも多い。今回、当科で施行した食道切除術症例における合併症、 予後等を年齢別、年代別に比較し、75 歳以上の高齢者に対する食道切除術の妥当性 を考察した。【方法】1964 年から 2006 年に施行した食道癌切除例 1131 例を、I 群（74 歳以下: 対象群) 1010 例、II 群（75-79 歳：高齢者群） 97 例、III 群（80 歳以上 : 超高齢者群）24例にわけ治療成績を比較した。さらに、前期（'64～’89 年、 $\mathrm{n}=451$ )、後期（'90 〜'10 年、n=680）にて変遷を多変量解析にて検討した。【結果】 術後合併症：各群 40、39、25\% と有意差はなかった。さらに、前後期ではI群 $49 \rightarrow 32 \%$, II 群 $51 \rightarrow 31 \%$, III 群 $38 \rightarrow 19$ \% と後期で減少し、なかでも肺合併症は I 群 $26 \rightarrow 11 \%$ 、II 群 $34 \rightarrow 15 \%$ 、III 群 $38 \rightarrow 0 \%$ と各群で減少していた (p<0.05)。合併症 発生の独立因子は、胸骨前または後経路、不完全切除、術前照射、前期であったが、 年齢は有意な因子ではなかった。予後 : 各群の 5 年全生存率は 34、27、7\%であった が (I-II 群間 P < 0.05)、原病生存率では差はなかった。【考察】高齢者、超高齢者の 食道切除は合併症発生、根治性の面で対象群と差はなく、後期では致死的な肺合併 症が減少するとともに予後も改善した。超高齡者においても食道切除は、㛜密な手術 適応と二期手術等による侵襲の軽減により、選択しうる治療法の一つである。

\section{PD10-5 85 歳以上の胃癌手術症例の検討}

岩崎善毅, 大橋学, 岩永知大, 大日向玲紀, 高橋慶一, 山口達郎, 松本寛, 中野大輔

がん・感染症センター都立駒込病院外科

【目的】 85 歳以上の超高齢者では、術前合併症併存率が高く、主要臓器の予備力が 低下しているため手術侵襲が大きくなり、耐術能が低い。今回は 85 歳以上の胃癌手術 症例を対象に、手術の安全性と有効性につき検討した。【対象と方法】2007 年以降に 当院で胃癌に対し、手術を行った 85 歳以上の 20 例を対象に術前状態や術後経過を 検討した。【結果】性別は男性 12 例、女性 8 例。手術時の年歯怜 85 歳から 93 歳 ( 中 央值; 87 歳)。全症例に基礎疾患を認めた。PS は PS0:3 例、PS1:12 例、PS2 : 5 例。 手術目的は症状緩和：3 例でその他は治癒切除目的であった。術式は胃全摘術 7 例、 幽門側胃切除 11 例、部分切除 1 例、胃空腸バイパス術は 1 例。 R0 手術は 12 例、 R1：4 例、R2：4 例。術後合併症しして譫妄や誤與性肺炎を認めたが、重篤例は認 めなかった。全例術後早期から経口摂取が可能であったが、6 例では補助栄養療法を 要した。術後に経口摂取不良や病状の進行に伴い再入院となる症例は 11 例であった。 早期癌は 7 例、進行癌は 13 例であったが術後早期に亡くなる症例は少なく、半数が 術後 1 年以上生存した。【とめ】術前合併症を有する 85 歳以上の胃癌症例であつても、 術後に重篤な合併症や高度のADL の低下は認められず、手術は安全に施行できると 考える。 


\section{PD10-6 80 歳以上超高齢者肺癌に対する外科治療とその変遷}

吉田月久, 矢野篤次郎, 河野幹寛, 波呂祥, 岡本龍郎, 前原喜彦

九州大学大学院 消化器・総合外科

【背景】 2011 年 8 月にわが国の 65 歳以上の人口は総人口の $23.2 \%$ となり、超高齢者 社会が形成されつつある。この社会構造の変化による肺癌年齢層の高齢化は、今後さ らに進むと考えられる。高齢者肺癌に対する外科治療について、当科の手術症例より 検討した。【対象・方法】1974 年から 2012 年 2 月までに当科にて外科的切除を行っ た未治療の原発性肺癌 2183 例のうち、80 歳以上の超高齢者肺癌 97 例を年代別に分 類し、臨床的特徵を比較検討した。【結果】超高齢者肺癌の症例数は徐々に増加が みられた $(70$ 年代 ; $0 \% 、 80$ 年代 ; $2.8 \% 、 90$ 年代 ; $3.1 \% 、 2000$ 年 ; $7.4 \%)$ 。試験開胸 は 6 例 (6.2\%)であった。2000 年以降とそれ以前を比較すると、非喫煙者 $(63.5 \% \mathrm{vs}$ $41.2 \%, \mathrm{p}=0.05)$ 、腺癌が多くみられた $(79.4 \%$ vs $47.1 \%, \mathrm{p}=0.04)$ 。また、腫瘍径は小さく なる傾向がみられ (31.9mm vs $37.8 \mathrm{~mm}, \mathrm{p}=0.16)$ 、術式は区域・楔状切除が多く施行さ れていた $(36.1 \%$ vs $16.7 \%, \mathrm{p}=0.09)$ 。 年生存率は 2000 年以降の症例で良好であった (75.0\% vs 35.3\%, p=0.02)。【結論】超高齢者肺癌は増えつつあり、葉切除未満手術が 適応と考えられる小径の腺癌が増えてきている可能性が考えられた。

\section{PD10-7 当科での超高齢者肝細胞癌肝切除術における外科治療成績}

海堀昌樹, 松井康輔, 石崎守彦, 坂口達馬, 松島英之, 中竹利知, 權雅憲 関西医科大学 外科

【目的】超高齢者（80 歳以上）肝癌術後成績を検討。また外科外来診察時の手術回 避例を検討。【方法】1）620 例肝癌切除術対象。手術時 75 歳未満 537 例（非高齢 者群）、75 歳以上 80 歳未満 59 例（高齢者群）と 80 歳以上 24 例（超高齢者群）の 比較検討。2) 内科過去 5 年間の肝癌初回治療は 191 例（80 歳以上 28 例）であり、 初回治療として肝切除が考慮されたが、手術へ至らなかった症例検討。【結果】1）術 前併存疾患は有意に高齢者・超高齢者群が多く、術前肝機能は高齢者・超高齢者群 が良好。術後せん妄は超高齢者群に有意に多かった。DFS・OS は 3 群間で差なし。 他病死を除く修正 5 年 OS は超高齢者 $64 \%$ 、高齢者 $63 \%$ 、非高齢者群 $55 \%$ 。多変量解 析における超高齢者の再発・生存の予後因子はそれぞれ術前 ALT $\geqq 24 I U / L$ と術後 合併症。2）初回治療しして肝切除が考慮されたが、手術へ至らなかった症例は 80 歳 以上 8 例。理由は心肺腎機能障害 1 例、脳梗塞後 1 例、認知症 1 例、手術拒否 5 例。 非高齢者と比較し有意に個人家人意思による手術拒否が多かった。考察】超高齢者 肝癌切除において術前併存疾患が多いにも関わらず、せん妄以外の術後合併症には 差を認めず。術後再発率、生存率も年齢による差を認めず。高齢者において腫瘍再発、 進展に関しては 75 歳未満と比較し不利とはならないが、術後他病死が多くなることが示 唆。高齢者肝切除は手術に対寸る不安が強く、回避される傾向もあるが、手術適応は 若年者と同等でよい。 


\section{PD11-1当院集中治療部における診断的腹腔洗浄法の有用性}

宮下知治 ${ }^{1}$, 谷口巧 ${ }^{1}$, 岡島正樹 ${ }^{1}$, 二宮致 ${ }^{2}$, 伏田幸夫 ${ }^{2}$, 藤村隆 ${ }^{2}$, 太田哲生 ${ }^{2}$

${ }^{1}$ 金沢大学病院 集中治療部, ${ }^{2}$ 金沢大学病院 消化器 - 乳腺 - 移植再生外科

【目的】診断的腹腔洗浄法（DPL）は鈍的腹部外傷に対する開腹適応の補助診断の 一つとして広く用いられている。当施設では診断が困難な腸管虚血症例等に対しても DPLを応用しており、非閉塞性腸管虚血（NOMI）の診断に有用であった症例を報告 寸る。【対象】 2009 年 1 月から 2010 年 12 月までに当院集中治療部にて DPLを施行 した症例は 4 例で、腹壁損傷を合併した脊椎損傷症例 1 例、腸管の低還流による NOMI が疑われた 3 例であった。いずれも DPL 施行前にCT 検査が施行され、腸管 損傷や腸管壊死などは指摘されていなかった。DPL の陽性基準は WBC $>500 / \mathrm{mm}^{3}$ と した。【結果】DPL は通常 2 日間施行している。春椎損傷例および NOMI が疑われた 3 例中 2 例で 2 日間とも WBC は陰性であったが、残りの 1 例は 1 回目で $1680 / \mathrm{mm}^{3}$ と 陽性であった。（DPL 陽性症例） CABG 手術後の心・呼吸・腎不全に対し、人工呼 吸器・血液浄化・循環作動薬による管理が行われていた。下痢が持続し CT 検査に て重症腸炎と診断されたが、感染制御が不良で再度 CT 検査を施行し腸管虚血が疑わ れた。小開腹にて腸管の色調を直接確認したが、確定診断が得られずDPLを施行し 陽性と診断された。直ちに緊急開腹術が施行され、S 状結腸の壊死と穿孔部を確認で きた。【結語】造影 CT 検查は腸管の血流障害および壊死を診断する際の第一選択検 査であるが、虚血性腸炎などが疑われ、CT 検査で開腹する根拠が明確でない症例で は DPL も有用な補助診断検査の一つと考えられた。

\section{PD11-2 救急医療における消化器外科医の関わりにおける諸問題と対策}

赤星朋比古 ${ }^{1}$, 永田高志 ${ }^{1}$, 橋爪誠 ${ }^{2}$

${ }^{1}$ 九州大学先端医療医学 災害救急医学, ${ }^{2}$ 九州大学大学院 消化器 - 総合外科 【はじめに】消化器外科医 ( 以下外科医) は日常診療では専門藏器のみを扱うことが多 く、救急患者の初療を行うことは少なくなった。【腹部救急疾患における諸問題と対策】 1. 診療体制: 臟器損傷を診る前に蘇生と生命維持に必要な呼吸循環も常に念頭に置 かなくてはならない。救急患者の初療を体系的に学ぶ機会に乏しい外科医が BLS、 ACLS などに基づき外傷初期診療を経験すべきである。2. 手術適応決定の判断 : 外科 医にとって内因性の腹膜炎等の手術決定は比較的容易であるが、外傷性腹腔内臟器 損傷に起因する出血や腹膜炎の判断は容易ではない。JATEC による外傷診療の標準 的診療に習熟するべきである。3.ICU における集中治療 : EGDT に基づいた循環管理。 Damage control 手術などの特殊な病態に留意した集中管理は、外傷外科手術だけで なく、通常の外科における大手術後の管理においても重要な概念である。今後の方策】 外科系学会教育集会における救急医学セミナ一あるいは救急部門による外科医の短期 研修制度などを検討すべきと考える。日本でもアメリカ外科学会認定の ATOM (advanced trauma operative management）コースが開催されている。JATEC コースが救急領域で の off the job training として運用され外傷期診療の標準化と普及に大きな役割をはたし たことから、本コースの Preventable trauma death 回避への効果が期待される。 
PD11-3 大規模災害において外傷外科医に求められる technical skill と non technical skill

永田高志 ${ }^{1,2}$, 赤星朋比古 ${ }^{1,2}$, 橋爪誠 ${ }^{1,2}$

${ }^{1}$ 九州大学先端医療イノベーションセンター, ${ }^{2}$ 九州大学病院救命救急センター はじめに:2011 年 3 月 11 日に発生した東日本大震災では当初想定された外傷患者は ほとんど見られず、防ぎ得た災害死を防ぐことを目指して組織された日本 DMAT は十分 な活動を行うことが出来なかった。一方で、今回の被災地では避難所の医療活動や検 視活動、緊急被ばく医療等が求められた。今回我々は近年の国内外の大規模災害の 報告を検証し、外傷外科医に求められる technical skill と non technical skill を検証した い。方法: 近年国内外で発生した死者 100 以上の大規模災害に関寸る報告書を検索 し系統的レビューを行った。結果: 1995 年阪神大震災では死者 6000 人を超え適切な 治療を提供すれば救命出来た可能性の外傷疾患が指摘された一方で避難所医療の必 要性も認識された。2004 年ロシア学校占拠事件では発生 4 日後に軍の強行突入が行 われ、人質開放 1 時間以内に 33 件の緊急手術が行われた。2011 年八イチ地震直後 に大規模野外病院を展開したイスラエル国防軍は整形外科の緊急手術のニーズが高 かったことを報告した。考察: 大規模災害において外傷外科医に求められる technical skill は体幹部臟器外傷の止血術に加え整形外科領域疾患が挙げられ、non technical skill は避難所医療や公衆衛生活動、検視、緊急被ばく医療など従来外傷外科医が扱 わないものであった。この結果を踏まえ将来我が国で想定される大規模災害に対する災 害医療の在り方を考えたい。

\section{PD11-4 救急研修トレーニングシステムにおける救急技能競技大会 (メディカルラ リー)の活用}

奥山稔朗，平川勝之，是永大輔 , 竹中賢治

地方独立行政法人福岡市立病院機構 福岡市民病院

【背景】救急科医師は院内での診療に加え、院外における事故や災害発生時の病院 前救急診療に深く関わる。近年、救急技能競技大会である「メディカルラリー」が全国 各地で活発に開催されるようになり、病院前・病院後の救急診療標準化の推進に寄与 している。【目的】 2007 年に「第 1 回福岡メディカルラリー」が開催され、当院からは 毎年初期研修医がチャレンジャーとして出場している。今回、救急科トレーニングシス テムにおける、初期研修医のメディカルラリー出場の意義を明らかにした。【方法と成績】 初期研修医は、1 个月間上級医師による指導・訓練を受け、その後本戦に臨む。訓練、 本戦を通じて、1.メディカルコントロール体制や災害発生時の病院前救急医療体制の 理解、2. 救急現場の状況評価と患者トリアージの方法、3. 心肺蘇生法、病院前外傷 診療などのプログラムの現場での適用、4. 職種間チームワークや指揮命令系統の重要 性、などを習得した。さらに公共の場で各チームと競い合うこと、結果として上位入賞を 果たすことにより、5. 救急医療の市民一の啓蒙の必要性の理解、6. 救急医療全体へ のより一層の興味、7. 医師としての爾後の大きな自信、が得られた。【結論】救急科トレー ニングの一環としてのメディカルラリー出場により、初期研修医の救急現場での臨床力 の向上、および救急医療体制への理解の広がりが得られると考えられた。 


\section{PD11-5 市中病院での外科系救急医を育成するための試み}

清水義博 $^{1}$, 内山清 ${ }^{1}$, 山本芳樹 ${ }^{1}$, 金修一 $^{1}$, 細野俊介 ${ }^{1}$, 二木元典 ${ }^{2}$

${ }^{1}$ 社会医療法人岡本病院（財団）第二岡本総合病院 外科, ${ }^{2}$ 社会医療法人岡本 病院（財団）第二岡本総合病院 救急部

当院は宇治市にある 2 次救急病院である。外科は定時手術の他、急性腹症、胸腹部 外傷の緊急手術に対応している。近年、重症外傷手術症例が減少し技術修得の機会 が少ないことが問題となっている。【目的・方法】過去 4 年間の外科手術症例を検討し、 2010 年度より外科系救急医を外科医として 1 名勤務させ technical skill 向上と外科での 多発外傷における non-technical skill の向上を検証し、急性期外科のあり方を提案する。 【結果】 2010 年度までの 4 年間の全麻手術件数は 845 例。28.8\% が緊急手術であった。 重症外傷手術症例は 9 例（肝損傷 1 、脾損傷 3、腸管損傷 4）に過ぎない。緊急手 術の大部分が内因性で、虫垂炎が 104 例 42.8\%を占める。結腸切除 28 例小腸切除 23 例、上部消化管潰瘍穿孔 11 例と続く。2 009 年度まで 5 人体制で、化学療法や緩 和も担当し多忙を極め、多発外傷に対寸る体制は無かった。2010 年度から救急科専 門医 1 名を外科に組み込み、がんの腹腔鏡下手術以外の内因性手術を平等に担当し、 外傷手術はチームリーダーを担当した。Technical skill 向上のため、比較的簡単な胃 瘦造設や鼠径へルニアを重点的に担当した。結果、救急医は週 1 件以上の執刀と 2 件の助手参加が得られた。多発外傷ではチームで damage control surgery が実践でき た。【考察】外科系救急医を外科に組み込む事は、外科医としての技術を高めると同 時に外科チームとしての non-technical skill が向上しうる体制と考えられた。

\section{PD11-6 外傷外科医に求められる technical skill と専門医との連携}

秋元寛，西本昌義，喜多村泰博，栗田晃宏

大阪府三島救命救急センター

外傷診療において, 頭部外傷から胸部, 腹部, 四肢外傷に至るまですべて一人の外 傷外科医が診療することは実質上不可能であり，各科専門医を有した外傷外科医が チームで診療に当たることとなる。三次救急医療施設を中心とした「近畿外傷診療フォー ラム」において外傷診療につきアンケート調査を行ったので，その結果から外傷外科医 に必要な technical skill について述べる。参加 12 施設の平均外傷手術症例は 115 例 / 年で，その内訳は整形外傷が $49 \%$, 頭部外傷 $25 \%$ と $3 / 4$ の症例で整形外科医，脳 外科医の治療が必要な外傷であった。一方，胸部，腹部外傷はそれぞれ $9 \% ， 16 \%$ と少ない。頭部外傷において, 穿頭術の $51 \%$ は救急医により行われていたが, 開頭血 腫除去, カテーテル手術は脳外科医が行っていた。胸部外傷では開胸止血術, 肺手術, 心大血管手術とも $50 \sim 70 \%$ は救急医が行っていた。腹部外傷では, 開腹止血術, 実質臓器手術，管腔臟器手術ともほぼすべて救急医が行っていた。これは外科系救 急医の多くが胸部外科, 腹部外科出身であることが考えられる。整形外傷では, カテー テル手術の $54 \%$ は救急医が行っているが，創外固定，観血的骨接合術はほぼすべて 専門医が行っていた。以上より, 現在外傷外科医に求められている skill は, 穿頭術, 胸腹部外傷手術, 骨盤骨折に対するカテーテル手術であり, それ以外の手術について は専門医との collaboration が必要である。 


\section{PD12-1 肺癌術後における ALI/ARDS 発症の予防戦略 - 周術期シベレスタット療 法の経験 -}

米谷卓郎, 稲毛輝長, 森本淳一, 坂入祐一, 山田義人, 岩田剛和, 千代雅子,

溝㴊輝明，守屋康充，吉田成利，吉野一郎

千葉大学 大学院 医学研究院 呼吸器病態外科学

【背景】肺切除後の重篤な合併症に、急性肺傷害 (ALI) および急性呼吸窮迫症候群 （ARDS）がある。発症率は、肺手術後の 2-4\% とされ、致死率は 35-64\%と高い。術 前化学放射線療法施行例、間質性肺炎 (IP) 合併例、慢性呼吸器感染症を有する症 例等が、ALI/ARDS 発症リスクが高いとされる。術後ALI/ARDS におけるシベレスタット の予防投与の意義については不明である。【目的】術後 ALI/ARDS 発症リスクの高い 肺癌切除症例におけるシベレスタットによる予防効果を retrospective に検討する。【対 象・方法】 2009 年 1 月より 2011 年 12 月における肺癌切除例のうち、上記 ALI/ARDS 発症リスク因子を有する症例に、シベレスタット $5 \mathrm{mg} / \mathrm{kg} /$ 日を術中より 7 日間持続静注。 【結果】 3 年間での肺癌切除術例 376 例のうち予防策の対象となったのは 33 例 $(8.8 \%)$ 。 ALI/ARDS 発症リスク因子の内訳は、放射線化学療法/化学療法 /IP/ COPD: $17 / 3 / 10 / 3$ 例。年齢中央值は 67 歳、男性 / 女性 : $30 / 3$ 例、組織型 : $\mathrm{Ad} / \mathrm{Sq} /$ その他: 19/10/4 例、臨床病期 : IA/IB/IIA/IIB/IIIA/IIIB/IV:3/6/2/3/17/2 例。術式 は部分切除 / 肺葉切除 / 全摘 : $2 / 30 / 1$ 例 (合併切除 13 例、気管支 / 血管形成 9 例 ) であった。ALI は IP 合併の完全VATS 右下葉切除 1 例に認め、術後 9 日目に発症し たが、術後 16 日目に死亡した。【結論】術後 ALI/ARDS に対するシベレスタットによる 予防策は有用である可能性があるが、前向き試験での検討が望まれる。

\section{PD12-2＼cjkstart肺癌術後再発の臨床経過と治療の現状 \\ 一多施設共同前向き観察研究—}

岡本龍郎，河野幹寬，吉田月久，波呂祥，矢野篤次郎，前原喜彦

九州大学大学院 消化器・総合外科

【背景と目的】非小細胞肺癌術後再発例に関する研究報告は少なく診療ガイドラインも ないため、治療は実地診療の中で行われることが多い。九州大学第 2 外科関連呼吸 器グループ（KLSS）では術後再発例の診療の現状を把握・検討するための多施設共 同観察研究を遂行中であり、現在までの経過を報告する。【患者と方法】2012 年 1 月 までに 13 施設から登録された非小細胞肺癌の術後再発 116 例の登録データから臨床 背景、再発形式、再発後初回治療について検討した。【結果】患者背景は男 /女： 76/40 例、再発時年齢中央值 73 歳（44 87）、PS は 0/1/2/3:60/43/9/4 であった。 再発時の病期 (r-Stage) は I/II/III/IV : 8/12/27/69、組織型は腺癌 / 扁平上皮癌 / 大 細胞癌 / 腺扁平上皮癌 / その他 : 81/20/3/5/7。手術から再発までの期間中央値は 13.8 ヶ月、再発形式は局所/遠隔 (土局所) / 2 次肺癌 : 31/81/4 であった。遠隔転移 部位は脳 / 骨 / 肺 / 副腎 / 肝 / その他 : 15/18/40/3/6/7、転移臓器数は平均 1.7。 再発後初回治療しして局所再発例の $68 \%$ に局所治療単独 ( 手術または放射線治療) が 行われた。遠隔再発例の $70 \%$ に全身化学療法が行われたが、単臟器遠隔再発では 44\%に局所治療単独が選択された。EGFR 遺伝子変異陽性例の $71 \%$ に初回に EGFRTKI が使用された。【結論】肺癌術後再発例は多様な集団であり、選択される治療法 は多岐にわたる。実地診療における再発形式別治療の解析は、今後の治療指針確立 に役立つものと期待される。 


\section{PD12-3 肺癌術後再発を来した超高齢者に対する治療経験}

斉藤元吉, 安田学, 市来嘉伸, 竹之山光広, 永島明

北九州市立医療センター 呼吸器外科

【背景】高齢者肺癌症例の増加に伴い術後再発症例に対する治療方針に悩む機会も 多くなっている。当科における高齢者非小細胞肺癌術後再発症例を検討寸ることで、 高齢者肺癌術後再発症例に対寸る治療戦略を考察する。【対象】1992 年 4 月から 2010 年 12 月までに当科で手術した 80 歳以上の非小細胞肺癌切除症例 135 例のうち、 術後再発した 37 症例を対象とし、治療内容、予後を検討した。【結果】男性 26 例 ・ 女性 11 例。手術時年齢 80-89 歳（平均 82 歳）、再発時年齢 80-90 歳（平均 83 歳）。 再発に対寸る治療は、無治療 26 例・治療 11 例。治療例の内容は、積極的治療 4 例（化学療法+放射線治療 2 例 - 化学療法のみ 1 例 - 切除 1 例）、症状緩和を目的 とした治療 7 例（放射線治療 6 例・局所化学療法 1 例）。再発確認後の治療群と無治 療群の 1 年生存率は $55 \%$ および $27 \%$ 、2 年生存率は $18 \%$ および $12 \%$ 。生存期間中央 值は 432 日および 151 日。再発確認後全生存期間は両群間に有意差を認めなかった $(\mathrm{p}=0.129)$ 。他病死症例を $8 \%$ （治療群 1 例：虚血性心疾患、無治療群 2 例 : 間質 性肺炎・脳血管疾患）認めた。【まとめ】超高齢者肺癌術後再発症例に対して症状緩 和を目的とした治療は合併症無く施行できた。再発治療を行った症例はいずれも PS 低 下を認めず、かつ社会環境が良好（家族のサポートあり）な症例であったが、再発治 療による生存期間の延長は認めなかった。他病死する症例もあり、再発治療は慎重に すべきと考えられる。

\section{PD12-4＼cjkstart悪性胸膜中皮腫に対する胸膜外肺全摘術後の再発治療}

岡本龍郎, 波呂祥, 河野幹寛, 吉田月久, 矢野篤次郎, 前原喜彦

九州大学大学院 消化器・総合外科

【背景と目的】胸膜悪性中皮腫には胸膜外肺全摘術を取り入れた集学的治療が試みら れているが、再発後治療に関する報告は少ない。当科において胸膜外肺全摘術の行 われた症例の術後経過および再発治療成績を検討する。【方法】 2001 年から 2011 年 までに当院で胸膜外肺全摘術が行われた 10 例の臨床経過を retrospective に検討した。 【結果】男性 9 例、女性 1 例、手術時の年齢中央値は58（48-66）歳であった。組 織型は上皮型 8 例、 2 相型 2 例、IMIG 病期は II 期 3 例、III 期 7 例であった。全生 存期間、無再発生存期間中央值は 49.6 ケ月、15.4 ケ月、全生存率、無再発生存率 は 2 年が $78.7 \% 、 40 \% 、 5$ 年が $27.8 \% 、 26.7 \%$ であった。8例（80\%）に術後再発を認 めており、胸部局所再発が 4 例（胸壁 2 例 / 縦隔 2 例、）で、局所外再発が 4 例（癌 性腹膜炎 2 例、肺転移 2 例）であった。再発後治療しして局所再発例には局所療法 土全身化学療法（手術 + 化学療法 1 例、局所放射線治療単独 2 例、局所放射線治 療 + 化学療法 1 例）が行われ、局所外再発例に対しては化学療法単独が行われた。 再発後の全生存期間中央值は 17.8 ケ月、 1 年、 2 年生存率は $62.5 、 23.4 \%$ であった。 【考察】胸膜外肺全摘後の再発形式のほとんどが局所進展経路であった。再発後に長 期生存を得るには効果的な局所コントロールと全身化学療法が重要と考えられた。 


\section{PD12-5 悪性胸膜中皮腫に対する Cisplatin +Pemetrexed の使用成績}

山口正史，豊川剛二 , 大場太郎，平井文彦，丸山理一郎，濱武基陽， 杉尾賢二, 一瀬幸人

国立病院機構 九州がんセンター 呼吸器腫瘍科

【背景】現時点で悪性胸膜中皮腫に対する化学療法としては Cisplatin (CDDP)+Pemetrexed (Pem) が第一選択とされ、適応である症例には手術や放射線治療 等との集学的治療が試みられている。【症例と方法】2005 年 8 月から 2011 年 10 月の 26 例について後方視的に検討した。平均年齢 60 (41-76) 歳、男性 / 女性 19/7 例、 PS $0 / 1$ が 21/5 例、臨床病期 Ia/Ib/II/III/IV 期各 2/7/2/7/8 例で、組織亜型は上皮 型／肉腫型／混合型／不明が各 18/3/3/2 例であった。全例に CDDP $75 \mathrm{mg} / \mathrm{m}^{2}+$ Pem $500 \mathrm{mg} / \mathrm{m}^{2}$ の 3 週毎投与が予定された。【結果】重篤な有害事象はなく、腫瘍効 果は検討可能な 24 例中、PR/SD/PD 各 4/17/3 例で、内 8 例に胸膜外肺全摘術、2 例に試験開胸（IV 期）が施行された。手術関連死亡は認めなかった。中間生存期間 は全 26 例、化学療法 16 例、胸膜外肺全摘 8 例の順に 25.3、22.0、33.4 ケ月であった。 【結語】悪性胸膜中皮腫に対寸る CDDP+Pem による化学療法により一定の抗腫瘍効果 が期待できる可能性がある。集学的治療における外科切除の適応決定には慎重な症例 選択と術後管理を要する。 